\title{
A coupled THMC model of a heating and hydration laboratory experiment in unsaturated compacted FEBEX bentonite
}

\author{
Liange Zheng ${ }^{1 *}$, Javier Samper ${ }^{1}$, Luis Montenegro ${ }^{1}$, and Ana María Fernández ${ }^{2}$ \\ (1) E. T. S. Ingenieros de Caminos, Universidad de la Coruña, Campus de Elviña s/n, 15192 La Coruña \\ e-mail: jsamper@udc.es \\ (*) Present address: Lawrence Berkeley National Laboratory, 1 Cyclotron Road, Berkeley, CA 94720, USA
}

\begin{abstract}
Unsaturated compacted bentonite is foreseen by several countries as a backfill and sealing material in high-level radioactive waste repositories. The strong interplays between thermal $(\mathrm{T})$, hydrodynamic $(\mathrm{H})$, mechanical $(\mathrm{M})$ and chemical $(\mathrm{C})$ processes during the hydration stage of a repository call for fully coupled THMC models. Validation of such THMC models is prevented by the lack of comprehensive THMC experiments and the difficulties of experimental methods to measure accurately the chemical composition of bentonite porewater. We present here a nonisothermal multiphase flow and multicomponent reactive solute transport model for a deformable medium of a heating and hydration experiment performed on a sample of compacted FEBEX bentonite. Besides standard solute transport and geochemical processes, the model accounts for solute cross diffusion and thermal and chemical osmosis. Bentonite swelling is solved with a statesurface approach. The THM model is calibrated with transient temperature data and water content and porosity data measured at the end of the experiment. The reactive transport model is calibrated with porewater chemical data derived from aqueous extract data. Model results confirm that thermal osmosis is relevant for the hydration of FEBEX bentonite while chemical osmosis can be safely neglected. Dilution and evaporation are the main processes controlling the concentration of conservative species. Dissolved cations are mostly affected by calcite dissolution-precipitation and cation exchange reactions. Dissolved sulfate is controlled by gypsum/anhydrite dissolutionprecipitation. $\mathrm{pH}$ is mostly buffered by protonation/deprotonation via surface complexation. The
\end{abstract}


model reproduces computed temperatures and water contents. Computed concentrations agree well with inferred aqueous extract data at all sections except near the hydration boundary where cation data are affected by a sampling artifact. The fit of $\mathrm{Cl}^{-}$data is excellent except for the data near the heater. The largest deviations of the model from inferred aqueous extract data occur for dissolved $\mathrm{SO}_{4}{ }^{2-}$ which is underpredicted by the model. There are uncertainties on the amount of gypsum available for dissolution and its dissolution mechanism (kinetics or local equilibrium).

Keywords: THMC model, FEBEX, compacted bentonite, thermal osmosis

\section{Introduction}

Compacted bentonite is foreseen in several countries as a backfill and sealing material for highlevel radioactive waste (HLW) disposal. FEBEX (Full-scale Engineered Barrier EXperiment) is a demonstration and research project dealing with the engineered barrier system (EBS) designed for sealing and containment of waste in a radioactive waste repository (EC, 2000). FEBEX is based on the Spanish reference concept for disposal of radioactive waste in crystalline rocks. Besides laboratory experiments, FEBEX includes two large-scale tests: the in situ test at the Grimsel underground laboratory (Switzerland) and the mock-up test at CIEMAT (Research Centre for Energy, Environment and Technology) facilities in Madrid (Spain) (EC, 2000; Alonso and Ledesma, 2005; ENRESA, 2006a). While bentonite hydration at the mock-up test takes place at a constant water pressure with no restrictions other than the infiltration capacity of bentonite, water inflow at the in situ test is controlled by local heterogeneities of the host rock. This distinctive feature of the mock-up test makes it more amenable for testing of numerical models of the EBS. The mock-up test provides valuable insight on the behaviour of bentonite buffer subjected to simultaneous heating and hydration and a thorough thermal, hydrodynamic and mechanical (THM) data set which have been used to calibrate THM parameters and test numerical models of compacted FEBEX bentonite (ENRESA, 2006a; Zheng and Samper, 2008). Chemical processes have been studied with a wide 
range of laboratory tests from which coupled thermal, hydrodynamic and chemical (THC) models were constructed (EC, 2000; Zheng, 2006) and key parameters were estimated (Samper et al., 2008c). Later, these models were tested with chemical data collected from partial dismantling of the FEBEX in situ test (ENRESA, 2006b; Samper et al., 2008b). The study of thermo-hydromechanical-chemical (THMC) processes in the bentonite barrier is a key point in performance assessment of a deep geological HLW repository. Sophisticated THC and THM codes have been developed. Existing THC codes include: TOUGH2-CHEM (White 1995), TOUGHREACT (Xu and Pruess 1998), RETRASO (Saaltink et al. 2004), MULTIFLO Lichtner (1996), and CRUNCH (Steefel 2001) which generally simulate multiphase THC processes by incorporating reactive transport in pre-existing codes. Multiphase flow models have been developed also within the realm of soil mechanics. They include: CODE_BRIGHT (Olivella et al., 1996), FADES (Navarro and Alonso, 2000) and FRACON (Nguyen et al., 2005). The influence of THM couplings on the safety of a HLW repository for spent fuel has been analyzed with different THM codes within the context of the DECOVALEX project by Chijimatsu et al. (2009). Coupled THMC models have been developed recently to study the coupled mechanical and chemical behaviour of the bentonite barrier of a HLW repository. Lately, CODE_BRIGHT has been updated to account for the effect of cation exchange on the mechanical behaviour of bentonite (Guimarães et al. 2007). Zheng and Samper (2008) presented a coupled THMC model of the mock-up test which accounts for thermal and chemical osmosis and bentonite swelling with a state-surface approach. The THMC model reproduces measured temperature and cumulative water inflow data. It fits also relative humidity data at the outer part of the buffer, but underestimates relative humidity near the heater. Their results show that $\mathrm{pH}$ is mostly controlled by surface complexation while dissolved cations concentrations are controlled by cation exchange reactions.

Development and testing of coupled THMC models is a great challenge, especially for the chemical aspects of the model due to the difficulties in measuring the porewater chemical 
composition of clays. Most existing experimental methods introduce perturbations which make difficult to get the 'true' chemical composition of bentonite porewater (Sacchi et al., 2001; Fernández et al., 2004; Zheng et al. 2008a).

Given the difficulties in measuring the chemical composition of clay porewaters, numerous laboratory techniques have been devised to extract water from clay samples (Sacchi et al., 2001). Squeezing and aqueous extract are the most commonly used methods. A large effort has been made during recent years to improve water extraction methods and achieve consistency between analytical data obtained from squeezing and aqueous extracts tests (Sacchi et al., 2001; Bradbury and Baeyens, 2003) and develop numerical interpretation methods (Zheng et al., 2008a). Squeezing and aqueous extraction methods alter the water-clay system in several ways and introduce sampling artifacts in measured data. Squeezing at high pressures may induce oxidation and dissolution of clay accessory minerals, outgassing of $\mathrm{CO}_{2}$ and chemical fractionation (Sacchi et al., 2001). Furthermore, squeezing does not allow extracting porewater from clay samples with water contents less than $20 \%$ (Fernández et al., 2004). This is the reason why squeezing data are not usually available near the heaters in heating and hydration experiments where samples have very low water content (Cuevas et al., 1997; EC, 2000). For samples with low water contents one must resort to aqueous extract tests (AET) in which a crushed sample is placed in contact with deionised water at a given solid-toliquid ratio. After establishing equilibrium, the solid phase is separated and the liquid phase is analyzed. Since AET may alter the geochemical system, indirect hydrogeochemical modelling is needed to infer the chemical composition of porewater from AET data. Zheng et al. (2008a) report a comprehensive inverse hydrochemical model for the interpretation of AET which accounts for acidbase, redox, aqueous complexation, mineral dissolution/precipitation, gas dissolution/ex-solution, cation exchange and surface complexation reactions. It has been tested with AET performed on bentonite samples taken from the FEBEX in situ test (Samper et al., 2008a) and the Ventilation Experiment at the Mont Terri laboratory (Zheng et al. 2008b). 
Another problem faced by THMC models is the identification of parameters which are difficult to measure. Some researchers have resorted to inverse methods to overcome this difficulty (Sun, 1994; Dai and Samper, 2004). The inverse approach provides a way to determine unknown model parameters by fitting the forward model output to measured data. Inverse algorithms have been used to estimate soil hydraulic properties from transient infiltration data (Eching et al., 1994; Šimunek and van Genuchten, 1996; Inoue et al., 1998; Pan and Wu, 1998; Dai et al., 2008), and recently, inverse methods have been used also for multicomponent reactive transport (Tebes-Stevens et al., 2001; Dai and Samper, 2004; Dai and Samper 2006; Dai et al., 2006; Samper et al., 2008c).

Heating and hydration experiments of compacted bentonite have been conducted at different space and time scales including laboratory tests (Cuevas et al., 1997; Villar et al., 2008) and largescale tests such as the FEBEX mock-up and in situ tests (ENRESA, 2006a). These experiments which have been performed for different purposes differ in the types of acquired data. The mock-up test provides a thorough thermal, hydrodynamic and mechanical (THM) data set which were used by Zheng and Samper (2008) to gain additional understanding on coupled THM processes and calibrate THM parameters This test, however, provides no geochemical data. Chemical calculations of THMC models were tested with geochemical data collected from the partial dismantling of in situ test performed at a gallery of the Grimsel site (Samper et al., 2008a). Contrary to mock up and in situ tests, laboratory heating and hydration tests provide thermal, hydrodynamic and geochemical data which allow testing THMC models. THC and THMC models of the heating and hydration of the cell CT18 of Cuevas et al. (1997) are reported by Xie et al. (2006) and Guimarães et al. (2007), respectively. None of these models considered surface complexation, a chemical reaction known to control the $\mathrm{pH}$ of bentonite porewater (Bradbury and Baeyens, 1997; 1998, 2003, Fernández, et al, 2001; 2004). Moreover, the models of Xie et al (2006) and Guimarães et al (2007) were tested with concentration data obtained with the squeezing method. 
Here we present a coupled THMC model of the heating and hydration laboratory experiment performed by CIEMAT on the cell CT23 on FEBEX bentonite. The model accounts for surface complexation and has been calibrated using inferred aqueous extract data which are deemed to be more reliable than squeezing data. .

The paper starts by presenting the THMC mathematical formulation. Then, its numerical implementation in INVERSE-FADES-CORE is briefly described. The numerical model of the heating and hydration experiment performed on the cell CT23 is presented. The paper ends with some conclusions.

\section{Mathematical formulation}

\subsection{Water Mass Balance}

Water mass balance is given by (Navarro and Alonso, 2000):

$$
\frac{D_{s} m^{w}}{D t}+m^{w} \nabla \cdot \mathbf{v}^{s}+\nabla \cdot\left(\rho^{l} X_{l}^{w} \mathbf{q}^{l}+\rho^{g} X_{g}^{v} \mathbf{q}^{g}+\mathbf{j}^{v}\right)=0
$$

where $D_{s}() / D t$ is the material derivative with respect to the solid particles which move with a velocity vector $\mathbf{v}^{s}(\mathrm{~m} / \mathrm{s}), \nabla \cdot()$ is the divergence operator, $\rho^{l}$ and $\rho^{g}$ are the bulk densities of the liquid and gaseous phases $\left(\mathrm{kg} / \mathrm{m}^{3}\right)$, respectively, $X_{l}^{w}$ is the mass fraction of water in the liquid phase, $X_{g}^{v}$ is the mass fraction of the vapour in the gas phase, $\mathbf{q}^{l}$ is the vector of volumetric liquid flux $(\mathrm{m} / \mathrm{s})$ which is given by Eq. (15) below, $\mathbf{q}^{g}$ is the vector of volumetric gas flux $(\mathrm{m} / \mathrm{s})$ which is given by Eq. (16) below, $\mathbf{j}^{v}$ is the dispersive mass flux of vapour with respect to the mean gas 
velocity $\left(\mathrm{kg} / \mathrm{m}^{2} / \mathrm{s}\right)$ which is given by Eq. (17), and $\mathrm{m}^{\mathrm{w}}$ is the mass of water per unit volume of porous medium $\left(\mathrm{kg} / \mathrm{m}^{3}\right)$ which is given by

$$
m^{w}=\phi\left[\rho^{l} X_{l}^{w} S_{l}+\rho^{g} X_{g}^{v}\left(1-S_{l}\right)\right]
$$

where $\phi$ is the porosity and $S_{l}$ is the liquid saturation degree.

\subsection{Air mass balance}

The air mass balance equation is given by (Navarro and Alonso, 2000):

$$
\frac{D_{s} m^{a}}{D t}+m^{a} \nabla \cdot \mathbf{v}^{s}+\nabla \cdot\left[X_{g}^{a} \rho^{g} \mathbf{q}^{g}+X_{l}^{a} \rho^{l} \mathbf{q}^{l}\right]=0
$$

where $X_{g}^{a}$ is the mass fraction of air in the gaseous phase, $X_{l}^{a}$ is the mass fraction of air in the liquid phase, and $m^{a}$ is the mass of air per unit volume of porous medium $\left(\mathrm{kg} / \mathrm{m}^{3}\right)$ which is given by:

$$
m^{a}=\rho^{g} X_{g}^{a} \phi\left(1-S_{l}\right)+\rho^{l} X_{l}^{a} \phi S_{l}
$$

\subsection{Solid mass balance}

The solid mass balance is given by (Navarro and Alonso, 2000):

$$
\frac{D_{s} \rho^{d}}{D t}+\rho^{d} \nabla \cdot \mathbf{v}^{s}=0
$$

where $\rho^{d}$ is the dry density of the medium which is equal to $\rho^{s}(1-\phi)$ where $\rho^{s}$ is the density of the solid particles $\left(\mathrm{kg} / \mathrm{m}^{3}\right)$. If the coefficient of the thermal expansion of solid particles $\left(1 /{ }^{\circ} \mathrm{C}\right), C_{T}^{S}$, is considered and the mechanical compressibility of the particles is disregarded, then Equation (5) becomes:

$$
\frac{D_{s} \phi}{D t}=(1-\phi)\left[\nabla \cdot \mathbf{v}^{s}-C_{T}^{s} \frac{D_{s} T}{D t}\right]
$$


where $T$ is the temperature $\left({ }^{\circ} \mathrm{C}\right)$.

\subsection{Energy balance}

Our formulation assumes that all phases and species are at local thermal equilibrium and therefore they are all at the same temperature. Hence, the energy balance is described in terms of an equation of internal energy which is defined by the following balance of enthalpy:

$$
\frac{D_{s} h}{D t}+h \nabla \cdot \mathbf{v}^{s}+\nabla \cdot\left(-\boldsymbol{\Lambda} \cdot \nabla T+\mathbf{I}^{e}\right)=0
$$

where $h$ is the average specific enthalpy of the soil $(\mathrm{J} / \mathrm{kg})$ which in turn is given by:

$$
h=\rho^{l} X_{l}^{w} \phi S_{l} h^{w}+\rho^{g} X_{g}^{v} \phi\left(1-S_{l}\right) h^{v}+\rho^{g} X_{g}^{a} \phi\left(1-S_{l}\right) h^{a}+\rho^{l} X_{l}^{a} \phi S_{l} h^{a}+\rho^{s}(1-\phi) h^{s}
$$

where $h^{w}, h^{v}, h^{a}$ and $h^{s}$ are the specific enthalpies of free water, vapour, air and solid particles respectively, which are assumed to depend linearly on temperature and specific heat (Navarro and Alonso, 2000) and $\mathbf{I}^{e}$ is the vector of convective energy flux which is given by:

$$
\mathbf{I}^{e}=\rho^{l} X_{l}^{w} h^{w} \mathbf{q}^{l}+\rho^{g} X_{g}^{v} h^{v} \mathbf{q}^{v}+\rho^{g} X_{g}^{a} h^{a} \mathbf{q}^{g}
$$

where $\mathbf{q}^{g}$ is the vector of volumetric vapour flux (m/s) which is given by the last terms of Eq. (1), that is, $\mathbf{q}^{v}=\rho^{g} X_{g}^{v} \mathbf{q}^{g}+\mathbf{j}^{v}$ and $\boldsymbol{\Lambda}$ is the bulk thermal conductivity tensor $\left(\mathrm{W} / \mathrm{m}^{\circ}{ }^{\circ} \mathrm{C}\right)$ which for unsaturated bentonite is computed as a volume-weighted average of the conductivities of the components according to:

$$
\boldsymbol{\Lambda}=\phi S_{l} \boldsymbol{\Lambda}^{w}+\phi\left(1-S_{l}\right)\left(\boldsymbol{\Lambda}^{v}+\boldsymbol{\Lambda}^{a}\right)+X_{l}^{a} \phi S_{l} \boldsymbol{\Lambda}^{a}+(1-\phi) \boldsymbol{\Lambda}^{s}
$$

where $\boldsymbol{\Lambda}^{w}, \boldsymbol{\Lambda}^{v}, \boldsymbol{\Lambda}^{a}$ and $\boldsymbol{\Lambda}^{s}$ are the thermal conductivities of water, vapour, air and solid, respectively. This equation is inspired in the formulation of De Vries's (1963) which according to Tang et al. (2008) provides the best fit to measured thermal conductivity data for several bentonites, including FEBEX bentonite. The formulation in Eq. (10), however, may not be the appropriate for courser porous materials. 
According to Soler (2001), the Dufour effect is negligible compared to thermal conduction and therefore can be disregarded.

\subsection{Mechanical Equilibrium Equation}

The following incremental formulation of the equilibrium equation of Navarro and Alonso (2000) is used:

$$
\nabla \cdot\left(\Delta \boldsymbol{\sigma}^{\prime}+\Delta \mathrm{p}^{\mathrm{g}} \delta\right)+\Delta \rho \mathrm{gk}=0
$$

where $\Delta \rho$ is the increment of the average soil density, $\mathrm{g}$ is the gravitational acceleration $\left(\mathrm{m} / \mathrm{s}^{2}\right), \mathbf{k}$ is the unit vector in the gravity direction, $\boldsymbol{\delta}$ is the vector expression of Kronecker's delta, $\Delta \mathrm{p}^{\mathrm{g}}$ is the increment in gas pressure $(\mathrm{Pa})$ which for saturated conditions should be replaced by $\Delta p^{l}$ the increment in liquid pressure $(\mathrm{Pa})$ and $\Delta \boldsymbol{\sigma}^{\prime}$ is the vector of increments of effective stress $(\mathrm{Pa})$ which is related to the vector of increments of total stress $\Delta \boldsymbol{\sigma}(\mathrm{Pa})$ in unsaturated conditions through:

$$
\Delta \boldsymbol{\sigma}^{\prime}=\Delta \boldsymbol{\sigma}-\Delta p^{g} \delta
$$

while for saturated conditions the previous equation is replaced by $\Delta \boldsymbol{\sigma}^{\prime}=\Delta \boldsymbol{\sigma}-\Delta p^{l} \delta$ (Fredlund and Rahardjo, 1993).

\subsection{Solute transport}

Solute transport processes include advection, molecular diffusion, and mechanical dispersion. Each of them produces a solute flux per unit surface and unit time. There are as many transport equations as primary chemical species in the system. The mass balance equation for the $\mathrm{j}$-th primary species is given by (Zheng and Samper, 2008):

$$
m_{l}^{w} \frac{\partial C_{j}}{\partial t}+\frac{\partial\left(m_{l}^{w} P_{j}\right)}{\partial t}+\frac{\partial\left(m_{l}^{w} W_{j}\right)}{\partial t}+\frac{\partial\left(m_{l}^{w} Y_{j}\right)}{\partial t}=L^{*}\left(C_{j}\right)+r_{i}\left(C_{j}^{0}-C_{j}\right) \quad \mathrm{j}=1,2, \ldots \mathrm{N}_{\mathrm{c}}
$$

$C_{j}$ is the total dissolved concentration of the of $\mathrm{j}$-th species $(\mathrm{mol} / \mathrm{L}), m_{l}^{w}$ is the mass of liquid water per unit volume of medium $\left(\mathrm{kg} / \mathrm{m}^{3}\right)$ which is equal to $\rho^{l} X_{l}^{w} \theta$ where $\theta=S_{l} \phi$ is the volumetric water content $\left(\mathrm{m}^{3} / \mathrm{m}^{3}\right), \mathrm{P}_{\mathrm{j}}, \mathrm{Y}_{\mathrm{j}}$ and $\mathrm{W}_{\mathrm{j}}$ are the total precipitated, sorbed and exchanged concentrations 
$(\mathrm{mol} / \mathrm{L})$, respectively, of the $\mathrm{j}$-th primary species, $\mathrm{r}_{\mathrm{i}}$ is the sink term $\left(\mathrm{kg} / \mathrm{m}^{2} / \mathrm{s}\right), \mathrm{C}_{\mathrm{j}}^{0}$ is the dissolved concentration of $j$-th species $(\mathrm{mol} / \mathrm{L})$ in the sink term $r_{i}, N_{C}$ is the number of primary species. $L^{*}()$ is the following transport operator:

$$
\mathrm{L}^{*}()=\nabla \cdot\left[m_{1}^{\mathrm{w}} \mathbf{D}^{\mathrm{j}} \cdot \nabla()\right]-m_{1}^{\mathrm{w}} \mathbf{q}^{l} \cdot \nabla()+\left(\mathrm{r}_{\mathrm{e}}-\mathrm{r}_{\mathrm{c}}\right)(\mathrm{)}
$$

where $\mathbf{D}^{j}$ is the dispersion coefficient $\left(\mathrm{m}^{2} / \mathrm{s}\right), r_{c}$ and $r_{e}$ are the condensation and evaporation rates $\left(\mathrm{kg} / \mathrm{m}^{2} / \mathrm{s}\right)$, respectively.

\subsection{Constitutive Equations}

Coupled transport phenomena such as thermal and chemical osmosis may be important for compacted bentonites (Keijzer et al., 1999; Keijzer and Loch, 2001; Soler, 2001). The volumetric liquid flux, $\mathbf{q}^{l}$, includes the classical Darcian term together with the chemical and thermal osmotic terms:

$$
\mathbf{q}^{l}=-\frac{\mathbf{k}^{i l} k^{r l}}{m}\left(\tilde{\mathrm{N}} p^{l}+r^{l} X_{l}^{w} g \tilde{\mathrm{N}} z\right)-k_{T} \tilde{\mathrm{N}} T+s \frac{\mathbf{k}^{i l} k^{r l}}{m^{l}} \tilde{\mathrm{N}} p_{h}
$$

where $p^{l}$ is the liquid pressure $(\mathrm{Pa}), \boldsymbol{k}^{i l}$ is the intrinsic permeability tensor of the liquid $\left(\mathrm{m}^{2}\right), k^{r l}$ is the relative permeability of the liquid, $\mu^{l}$ is the viscosity of the liquid $(\mathrm{kg} / \mathrm{m} / \mathrm{s}), z$ is the elevation, $k_{T}$ is the thermal osmotic permeability $\left(\mathrm{m}^{2} / \mathrm{K} / \mathrm{s}\right), p_{h}$ is the osmotic pressure $(\mathrm{Pa})$, and $\sigma$ is a dimensionless reflection coefficient for chemical osmosis which measures the non-ideality of a membrane and is defined as the ratio of the applied osmotic pressure to the developed hydraulic pressure at equilibrium. An ideal membrane has a reflection coefficient of 1 whereas it varies between 0 and 1 for non-ideal membranes.

The volumetric gas flux, $\mathbf{q}^{g}$, is given by:

$$
\mathbf{q}^{g}=-\frac{\mathbf{k}^{i g} k^{r g}}{m^{g}}\left(\tilde{\mathrm{N}} p^{g}+r^{g} g \tilde{\mathrm{N}} z\right)
$$

where $\boldsymbol{k}^{i g}$ is the intrinsic permeability tensor of the gas $\left(\mathrm{m}^{2}\right), k^{r g}$ is the relative permeability of gas, and $\mu^{g}$ is the viscosity of the gas phase $(\mathrm{kg} / \mathrm{m} / \mathrm{s})$. 
The dispersive mass flux of vapour, $\mathbf{j}^{v}$, is calculated by Fick's law:

$$
\mathbf{j}^{v}=-\rho^{g} \mathbf{D}^{v} \nabla X_{g}^{v}
$$

where $\mathbf{D}^{v}$ is the hydrodynamic dispersion tensor for vapour $\left(\mathrm{m}^{2} / \mathrm{s}\right)$ which includes the effects of mechanical dispersion and molecular diffusion. The effective molecular diffusion coefficient for the vapour, $D_{e}^{v},\left(\mathrm{~m}^{2} / \mathrm{s}\right)$ is calculated from (Pollock, 1986):

$$
D_{e}^{v}=\frac{5.9 \times 10^{-6} \tau^{v}(T+273.15)^{2.3}}{p^{g}}
$$

where $\tau^{v}$ is the vapour tortuosity (dimensionless).

\subsection{Mechanical model}

The mechanical law is given by:

$$
d \boldsymbol{\varepsilon}=\mathbf{C} d \boldsymbol{\sigma}^{\prime}+\boldsymbol{\beta} d \psi+\boldsymbol{\alpha} d T
$$

where $\varepsilon$ is the strain vector, $\mathbf{C}$ is the elastic matrix $(1 / \mathrm{Pa}), \boldsymbol{\beta}$ is a vector of coefficients $(1 / \mathrm{Pa})$ which account for the deformation caused by changes in suction $\psi, \psi=\left(p^{l}-p^{g}\right)$, and $\boldsymbol{\alpha}$ is a vector of thermal expansion coefficients $\left(1 /{ }^{\circ} \mathrm{C}\right)$. The standard sign convention used in Soil Mechanics is adopted here according to which compressions are positive.

Bentonite swelling can be calculated in several ways. One of them is based on the GouyChapman diffuse double layer (DDL) theory. Komine and Ogata (1996; 2003) derived a constitutive equation to relate the deformation of compacted bentonite with the distance between two montmorillonite layers. Xie et al. (2004) performed an upscaling procedure to relate the porosity to the thickness of DDL. This method, however, can be applied to a limited range of swelling pressures (Komine and Ogata, 1996) and particle spacings (Komine and Ogata, 2003) and cannot be used for transient bentonite swelling (Komine and Ogata, 1996; Komine and Ogata, 2003; Xie et al., 2004).

Swelling can be computed with elastoplastic models (Gens and Alonso, 1992; Thomas and He, 1998) such as the Barcelona Basic Model (BBM) (Alonso et al., 1990) and the Barcelona 
Expansive Model (BExM) (Alonso et al., 1999). The elastoplastic model has been further extended to account for macro- and micro-structures of expansive clays (Alonso et al., 1999; Thomas and Cleall, 1999; Sánchez et al., 2005) and the effect of cation exchange on swelling (Guimarães et al. 2007). Elastoplastic models require many parameters some of which are difficult to obtain experimentally. To overcome the difficulties of these models, some researchers have resorted to simpler models such as the state-surface approach to simulate bentonite swelling. Nguyen et al. (2005) used successfully the state-surface approach to interpret a swelling pressure test. The following state-surface expression of Lloret and Alonso (1995) is adopted here to model bentonite swelling:

$$
e=A+B \ln \sigma^{\prime}+C \ln \left(\psi+p^{a}\right)+D \ln \sigma^{\prime} \ln \left(\psi+p^{a}\right)
$$

where $e$ is the void ratio which is equal to the volume of voids divided by the volume of the solids; $p^{a}$ is the atmospheric pressure in $\mathrm{Pa}, \sigma^{\prime}$ is the mean effective stress in $\mathrm{Pa} ; \psi$ is suction in $\mathrm{Pa}$, and

A, B, C and D are empirical constants which for FEBEX compacted bentonite are A $=0.76$, $\mathrm{B}=-0.052446, \mathrm{C}=-0.0406413$ and $\mathrm{D}=0.00479977$ (Nguyen et al., 2005).

\subsection{Chemical reactions}

The chemical model accounts for the following reactions: aqueous complexation, acid/base, cation exchange, surface complexation and mineral dissolution/precipitation. All of them are assumed at local equilibrium. The chemical system is defined in terms of the concentrations of the following primary species: $\mathrm{H}_{2} \mathrm{O}, \mathrm{H}^{+}, \mathrm{Ca}^{2+}, \mathrm{Mg}^{2+}, \mathrm{Na}^{+}, \mathrm{K}^{+}, \mathrm{Cl}^{-}, \mathrm{SO}_{4}{ }^{2-}, \mathrm{HCO}_{3}^{-}$and $\mathrm{SiO}_{2}$ (aq). Concentrations of secondary species are computed from concentrations of primary species through appropriate mass action laws (Xu et al., 1999). Concentrations of precipitated, exchanged and adsorbed species are computed using similar equations. A detailed description of calculations of chemical reactions can be found in $\mathrm{Xu}$ et al. (1999). Aqueous complexes were identified from speciation runs performed with EQ3/6 (Wolery, 1992). Their equilibrium constants as well as those of minerals, exchange reactions and surface complexation reactions at $25{ }^{\circ} \mathrm{C}$ are listed in Table 1 . 
The Gaines-Thomas convention is used for cation exchange. Selectivity coefficients in Table 1 are taken from the THC model of the FEBEX mock-up and in situ tests (ENRESA, 2006b; Samper et al., 2008a; Zheng and Samper, 2008). Surface complexation is modelled using three types of protonation/deprotonation sites, $\mathrm{S}^{\mathrm{S}} \mathrm{OH}, \mathrm{S}^{\mathrm{W} 1} \mathrm{OH}$ and $\mathrm{S}^{\mathrm{W} 2} \mathrm{OH}$, as proposed by Bradbury and Baeyens (1997). Chemical reactions and constants for protonation/deprotonation by surface complexation are listed in Table 1.

Equilibrium constants for aqueous complexes and minerals change with temperature under non-isothermal conditions. They are calculated with the following expression which is valid for temperatures between 0 and $300^{\circ} \mathrm{C}$ :

$$
\log \mathrm{K}(\mathrm{T})=\frac{b_{1}}{T^{2}}+\frac{b_{2}}{T}+b_{3} \ln T+b_{4}+b_{5} T
$$

where $b_{1}$ to $b_{5}$ are coefficients which are derived by fitting Equation (21) to measured $\log K$ values at $0,25,60,100$ and $300^{\circ} \mathrm{C}$ (Wolery, 1992).

The thermodynamic database of EQ3/6 (Wolery, 1992) is used for aqueous complexes and minerals. The solubilities of gypsum and anhydrite as well as the temperature of conversion of gypsum to anhydrite obtained with the database of EQ3/6 have been compared to those derived from the PHREEQC database (Parkhurst and Appelo 1999). For the conditions of the cell CT23 the transition temperature is equal to $43^{\circ} \mathrm{C}$ when the $\mathrm{EQ} 3 / 6$ database is used whereas such temperature is $57^{\circ} \mathrm{C}$ when PHREEQC is employed. The latter is close to the commonly accepted value of $54^{\circ} \mathrm{C}$ (García Ruiz et al., 2007). It is found that the transition temperature decreases when the salinity of the solution increases.

\section{Numerical implementation}

The previous formulation has been implemented in INVERSE-FADES-CORE, a general code developed by integrating a THM code, FADES (Navarro and Alonso, 2000), a reactive transport code CORE $^{2 \mathrm{D}}$ (Samper et al., 2000; 2009) and the inverse methodology of Dai and Samper (2004; 2006) and Dai et al. (2006). FADES allows the simulation of the coupled thermo-hydro-mechanical 
behaviour of unsaturated soils (Navarro and Alonso, 2000). CORE $^{2 \mathrm{D}}$ is a 2-D finite element multicomponent reactive transport code which accounts for a wide range of chemical reactions. It has been extensively used to model laboratory and in situ experiments including CERBERUS Experiment in Boom clay (Samper et al. 2006; Zhang et al., 2008), interpret the Redox Zone Experiment in a fracture zone of the Äspö site (Molinero and Samper, 2004; Molinero et al. 2004; Molinero and Samper, 2006), evaluate the long-term geochemical evolution of radioactive waste repositories in clay (Yang et al., 2008) and granite (Yang et al., 2007), model the transport of corrosion products and their geochemical interactions with bentonite (Samper et al., 2008c), analyze stochastic transport and multicomponent competitive cation exchange in aquifers (Samper and Yang, 2006) and study concrete degradation (Galíndez et al., 2006). The integration of FADES and CORE $^{2 \mathrm{D}}$ (code FADES-CORE) was completed by Juncosa (2001). FADES-CORE was used to model multiphase flow and reactive transport through FEBEX bentonite in the first phase of the FEBEX project (EC, 2000). Later, FADES-CORE was updated by incorporating additional features such as: 1) A constitutive law for hydraulic permeability as a function of ionic strength, 2) Thermal osmosis; 3) Chemical osmosis; 4) Solute cross diffusion; and 5) Pitzer equations to calculate activity coefficients for high-salinity solutions (ENRESA 2006b).

INVERSE-FADES-CORE copes with both direct and inverse coupled THMC modelling of 1-, 2- and 3-D axi-symmetric problems. Bentonite swelling is solved with a state-surface approach. The state variables in INVERSE-FADES-CORE are $p^{l}, p^{g}, T$, displacement, $u$ and concentrations of the $N_{\mathrm{C}}$ primary species, $c_{j}$. Non-linear multiphase flow, mechanical and energy equations are solved simultaneously with a Newton-Raphson method to obtain $p^{l}, p^{g}, T$ and $u$. Then, reactive transport equations are solved by a sequential iteration method in which transport and chemical equations are solved separately in a sequential manner. Transport equations are solved first and then chemical reactions. This sequence is repeated until convergence is attained for a prescribed tolerance (Xu et al., 1999; Samper et al., 2009). The feedback between reactive transport and THM 
processes is accounted for in an explicit manner when changes in porewater ionic strength are large (Juncosa 2001). When chemical osmosis is considered, the osmotic pressure is computed from concentrations calculated at the previous time step. Details of the numerical features of the forward model can be found in Navarro and Alonso (2000). INVERSE-FADES-CORE solves the inverse problem by using an adapted version of the inverse algorithm of INVERSE-CORE (Dai and Samper, 2004). Forward routines of INVERSE-FADES-CORE have been widely verified with analytical solutions and tested with the simulation of THC problems (Samper et al., 2008b; Zheng et al., 2008b) and THMC processes (Zheng and Samper, 2008).

\section{Heating and Hydration Experiment on the cell CT23}

A series of laboratory tests were performed within the FEBEX project to study water flow and reactive solute transport in compacted bentonite during simultaneous heating and hydration. One of such tests was performed on the cell CT23 (EC, 2000). A $4.29 \mathrm{~kg}$ FEBEX bentonite block with 13 $\mathrm{cm}$ in height and $15 \mathrm{~cm}$ of diameter was placed in a stainless steel cylindrical hermetic cell (Fig. 1). A heater maintained a constant temperature of $87.5^{\circ} \mathrm{C}$ in the upper part of the cell. At the same time, the lower part of the bentonite block was hydrated with distilled water injected at a pressure of $1 \mathrm{MPa}$ through a $2.4 \mathrm{~cm}$ thick porous stone. The initial dry density of the bentonite is $1.65 \mathrm{~g} / \mathrm{cm}^{3}$. After 183 days of heating and hydration, the bentonite sample took $486 \mathrm{~cm}^{3}$ of water and its gravimetric water content increased from $13.3 \%$ at $\mathrm{t}=0$ (initial saturation degree of $56.4 \%$ ) to an average water content of $26.1 \%$ (saturation degree of $94 \%$ ). At $t=183$ days the heater was switched off, hydration was stopped and the bentonite sample was allowed to reach the ambient temperature. Then, the bentonite block was sliced into five sections. Section 1 near the heater has a thickness of $1.01 \mathrm{~cm}$. Sections 2 to 5 are $3 \mathrm{~cm}$ thick (Fig. 2). A half of each section was subdivided into 3 samples to perform aqueous extract tests and measure exchanged cations. The other half of each section was used to extract porewater by squeezing in sections 2 to 5 . After dismantling of the cell, the hydraulic conductivity, the swelling capacity and the fabric of the bentonite were measured to 
evaluate the effect of heating and hydration on physical, chemical and hydromechanical properties of the bentonite (EC, 2000; ENRESA 2006a).

\section{THMC Numerical Model}

\subsection{Numerical model}

The model includes two material zones (Fig. 3): compacted bentonite $(0<\mathrm{z}<0.138 \mathrm{~m})$ and the porous stone $(-0.024<\mathrm{z}<0)$. A uniform liquid pressure of $1 \mathrm{MPa}$ is adopted for the porous stone which is assumed to lack deformation. Backwards solute diffusion is allowed to take place in the porous stone. The model includes a heating and hydration stage, $0<\mathrm{t}<183$ days, and a cooling stage $183<\mathrm{t}<183.13$ days during which no further hydration is allowed.

Parameters of the THMC model are listed in Tables 2 to 4 . Some parameters such as the intrinsic permeability of the liquid were derived from laboratory experiments (EC, 2000; ENRESA 2006b). Other parameters such as the relative permeability of liquid and intrinsic permeability of gas were obtained from the calibration of the THMC model of the mock up test (Zheng and Samper, 2008). Parameters for which there are no measured data such as the reflection coefficient and the thermo-osmotic permeability were derived by sensitivity and inverse analyses.

The key parameter for chemical osmosis is the reflection coefficient. Keijzer et al. (1999) and Keijzer and Loch (2001) reported reflection coefficients from 0.001 to 0.3 for compacted Nabentonite and from 0.015 to 0.03 for Wyoming bentonite. Soler (2001) used a reflection coefficient of 0.1 for Opalinus clay. A reflection coefficient of 0.2 was adopted for the reference model of the cell CT23.

There are few experimental data on thermo-osmotic permeability, $k_{T}$. Soler (2001) provided plausible values of $k_{T}$ based on experimental studies on compacted clays which range from $10^{-14}$ to $10^{-10} \mathrm{~m}^{2} / \mathrm{K} / \mathrm{s}$. Zhou et al. (1999) tested different values of $k_{T}$ ranging from zero to $5.4 \times 10^{-12}$. Ghassemi and Diek (2002) used a thermo-osmotic permeability of $6 \times 10^{-11} \mathrm{~m}^{2} / \mathrm{K} / \mathrm{s}$ in their study of 
the stability of a swelling shale in a well. Given the lack of $k_{T}$ data, the sensitivity of water contents was evaluated for the following values of $k_{T}: 0,4.2 \times 10^{-13}$ and $10^{-12} \mathrm{~m}^{2} / \mathrm{K} / \mathrm{s}$.

The following boundary conditions are used for the THMC model:

$$
\begin{gathered}
p^{l}(-0.024 \leq z \leq 0, t \geq 0)=10^{6} \\
q^{l}(z=0.138, t \geq 0)=0 \\
q^{g}(z=-0.024, t \geq 0)=0 \\
q^{g}(z=0.138, t \geq 0)=0 \\
T(z=0.138,0 \leq t \leq 183)=87.5 \\
T(z=0.138,183 \leq t \leq 183.13)=20 \\
u(-0.024 \leq z \leq 0, t \geq 0)=0 \\
\sigma(z=0.138, t \geq 0)=2.5 \times 10^{5}
\end{gathered}
$$

where $q^{l}$ and $q^{g}$ are the liquid and gas fluxes, respectively, $u$ is the vertical displacement, $\mathrm{z}=0$ corresponds to the bottom of the cell at the interface of the porous stone and bentonite and $\mathrm{z}=0.138$ $\mathrm{m}$ corresponds to the bentonite-heater interface. A zero vertical displacement $v$ is imposed at the bottom part of the cell while the total stress is prescribed to $2.5 \times 10^{5} \mathrm{~Pa}$ at $\mathrm{z}=0.138 \mathrm{~m}$ to allow for displacements at this boundary given the existence of a gap between the bentonite block and the heater.

A Cauchy condition was used for the energy equation at the bottom of the cell according to which the heat flux, $Q_{\mathrm{c}}$, is computed from:

$$
Q_{c}=\alpha_{T}\left(T-T^{*}\right)
$$

where $\alpha_{T}$ is a thermal coefficient which was calibrated to a value of $801.6 \mathrm{~W} /{ }^{\circ} \mathrm{C}$ and $T^{*}$ is the external temperature which is equal to $20^{\circ} \mathrm{C}$. 
A Neuman boundary condition is used for solute transport at the bottom boundary according to which solute flux is equal to the product of water flux times solute concentration of inflow water which is distilled water. The $\mathrm{pH}$ of distilled water in contact with atmospheric air is usually around 5.6. However, the $\mathrm{pH}$ of distilled water that is kept out of contact with the atmosphere is about 7 . In cell CT23 experiment, inflow water was stored in a closed bottle without contact air during the entire test. In addition, the $\mathrm{pH}$ was measured before the beginning of the experiment. Its value was 7 . A sensitivity run was conducted in which the $\mathrm{pH}$ of boundary water was changed from 7 to 5.7 and the bicarbonate concentration from 0 to $2.510^{-6} \mathrm{M}$. Model results are not sensitive to changes in the $\mathrm{pH}$ of the inflow water because the $\mathrm{pH}$ of bentonite porewater is strongly buffered by surface complexation protonation.

Bentonite has an initial porosity of 0.39 and a gravimetric water content of $13.3 \%$ which corresponds to a saturation degree of $59.6 \%$ and a suction of $1.12 \times 10^{8} \mathrm{~Pa}$. The initial temperature is uniform and equal to $20^{\circ} \mathrm{C}$. The initial stress in bentonite is assumed isotropic and equal to $2.5 \times 10^{5}$ $\mathrm{Pa}$. The initial gas pressure is equal to the atmospheric pressure.

The porous stone has a porosity of 0.5 and is assumed to be always saturated. The effective diffusion coefficient, $D_{\mathrm{e}}$, is assumed to be the same for all chemical species. For compacted bentonite $D_{\mathrm{e}}$ is estimated from $\mathrm{Cl}^{-}$inferred aqueous extract data while for the porous stone is equal to $8 \times 10^{-11} \mathrm{~m}^{2} / \mathrm{s}$. It should be noticed that backwards diffusion may occur and therefore the chemical composition of the water in the porous stone may change.

The initial amount of gypsum in bentonite is a source of uncertainty in the inference of the porewater chemistry from aqueous extract data. Mineralogical analyses of FEBEX bentonite based on chemical normative calculations show that raw FEBEX bentonite samples contain about 0.14 $\mathrm{wt} \%(0.08 \mathrm{v} \%)$ of gypsum for a gravimetric water content of 14\% (ENRESA, 2006a).

The initial concentrations of the primary species in the bentonite sample were taken from Fernández et al. (2001) who derived them from measured aqueous extract data (see Table 5). They 
reported difficulties in reproducing the sulfate concentration when bentonite porewater was assumed in equilibrium with gypsum. Therefore, it is estimated that most of the gypsum is dissolved in the porewater at a gravimetric water content of $14 \%$.

Tables 6 to 8 list the initial site capacities for surface complexation, initial cation occupancies and initial volume fraction for minerals, respectively.

Temperatures were measured during the experiment while gravimetric water content, porosity, and the chemical composition of interstitial porewater were measured in cooled samples taken after 183 days of heating and hydration.

\subsection{THM model results}

Model thermal results reproduce generally measured temperature data at early times (Fig. 4). Heat transfer takes about 1 day to reach steady state. Computed temperatures at 183 days, however, overestimate measured data in the middle of the sample (Fig. 5). Measured temperatures in the middle of the cell are smaller than those computed with the 1-D model due possibly to a combination of: 1) Heat dissipation through the side walls of the steel carcase, a process which is not taken into account in the model, 2) Heat sinks and sources associated with evaporation and condensation, and 3) Underestimation of vapour transport.

The sensitivity of computed water contents to changes in the reflection coefficient was evaluated for reflection coefficients equal to $0.002,0.02$ and 0.2 respectively. Model results (not shown here) lack sensitivity to the reflection coefficient because chemical osmotic suction accounts for less than $1 \%$ of the total matrix suction. Therefore, chemical osmosis can be safely neglected for compacted FEBEX bentonite at the conditions of the cell CT23.

The sensitivity of the spatial distribution of computed water contents to changes in the thermoosmotic permeability, $k_{T}$ is shown in Figure 6 . Computed water contents are sensitive to changes in the thermal-osmotic permeability. The optimum value of $k_{T}\left(4.2 \times 10^{-13} \mathrm{~m}^{2} / \mathrm{K} / \mathrm{s}\right)$ is obtained by inverse fitting the measured gravimetric water content data. It could be argued that a model without 
thermal osmosis provides a good enough fit to the measured final water content with just a mild overestimation of water contents near the heater. Taking into account that the bentonite may swell during dismantling, there are uncertainties on: 1) The measured water contents after dismantling and 2) The model of the dismantling process. It is difficult to judge the relevance of thermo-osmosis from water content data of the cell CT23. However, the fact that the model with thermal osmosis performs better than that without thermal osmosis provides additional support for the findings of Zheng and Samper (2008) who concluded that thermal osmosis could be relevant for liquid flow through compacted FEBEX bentonite at spatial and temporal scales larger than those of cell CT 23.

Although measured data are not available at intermediate times, the good fit of the model to water content data at the end of the experiment (Fig. 6) is useful to test the performance of the THM model. The cell CT23 was designed primarily for hydrodynamic and geochemical characterization of compacted bentonite. Measured porosities at the end of the experiment are the only available data to test the mechanical model. Fig. 7 shows the spatial distribution of computed porosities at different times. Bentonite swells initially near the hydration side $(z=0)$ and shrinks near the heater due to the thermal compression and the water evaporation. Measured initial porosity is 0.39 and the average porosity measured after heating and hydration is 0.43 . This increase in the computed apparent porosity of the bentonite is possible because the bentonite filled the initial gap between the sample and the cylindrical steel carcase. The model accounts for this gap by allowing for the vertical displacement of bentonite/heater interface. Model results reproduce the general trend of porosity distribution. However, porosity is slightly overestimated near the heater possibly due to uncertainties in the mechanical parameters, limitations of the mechanical model of Equation 20 and the assumption of free displacement at bentonite/heater boundary.

\subsection{Inference of porewater chemical composition}

The composition of the bentonite porewater has been obtained in the laboratory with squeezing and aqueous extract tests (AET). Squeezing is the process of expulsion of the porewater from a 
saturated material by applying a large hydraulic pressure (64 MPa in samples of the cell CT23). Squeezing at high pressures may induce oxidation and dissolution of clay accessory minerals, outgassing of $\mathrm{CO}_{2}$, and dilution due to the extraction of water from the interlayers (Sacchi et al., 2001). Furthermore, squeezing does not allow to extract porewater from clay samples with water contents less than 20\% (Fernández et al., 2004). For low water contents one must resort to aqueous extract tests (AET) which provide a method to quantify the total content of soluble salts of a clay sample. An 1:R aqueous extract test consists on adding to a mass $M_{s}$ of powdered clay sample a mass of distilled water equal to $R$ times $M_{s}$. The clay sample and the water are stirred during 2 days. Chemical analyses are performed on supernatant solution after phase separation by centrifugation (Sacchi et al., 2001). Besides dilution, dissolution of soluble minerals such as sulphates and carbonates, dissolution and ex-solution of gases, cation exchange and surface complexation various chemical processes may occur during porewater extraction. All these reactions perturb concentrations of dissolved species in a complex manner and make difficult to derive the chemical composition of the original (before aqueous extraction) clay porewater from aqueous extract data. The inverse numerical method of Zheng et al. (2008a) to infer clay porewater chemical composition from aqueous extract data is based on the definition of a geochemical model (GM) for the claywater system. The GM for a clay sample is defined in terms of relevant chemical processes taking place during aqueous extraction. Identification of GM requires knowing: 1) Aqueous complexes, 2) Mineral phases and their initial volume fractions and equilibrium constants, 3) Cation exchange reactions, cation exchange capacity (CEC) and cation selectivities, 4) Surface complexation reactions, types of sites, densities and protolysis constants, and 5) Gas phases, pressures and conditions (open or closed). Since the appropriate GM may not be known a priori, it has to be improved in an iterative manner. The method starts from an initial GM and a guess of sample porewater concentrations, $c_{i}$. The inverse model accounts for the perturbations caused by aqueous extraction and provides the optimum estimates of $c_{i}$ which are those which minimize the differences 
between measured and computed aqueous extracts concentrations. For the interpretation of AET of the cell CT23, dissolved $\mathrm{HCO}_{3}{ }^{-}$is derived by assuming that samples are in equilibrium with respect to calcite. No gases are considered in the geochemical model because the cell CT23 is a closed system.

There are significant differences between measured and inferred AET data. Such differences are not constant because concentrations change during the aqueous extract tests due to dilution, calcite dissolution and cation exchange reactions. This effect can be clearly seen for K (see Fig. 17).

Clay samples for squezing tests are much larger than those used for AET. In fact, in a given section of the cell, squeezing is performed on one half of the section while aqueous extract tests are performed on three samples taken from the other half (see Fig 2). Therefore, squeezing data show less variability than inferred AET data which in each section show some scatter (see Fig. 13-19). Such scatter is noticeable for dissolved $\mathrm{Na}^{+}$and $\mathrm{K}^{+}$(Fig. 16 and 17). Furthermore, compacted FEBEX bentonite may act as a semi-permeable membrane thus allowing only pure water passing through it. Water and ions may not be squeezed at the same rate during the squeezing tests. Water is more squeezed than ions. This means that the solution squeezed out is diluted compared to the bentonite porewater. This dilution is a major disadvantage of the squeezing test that tends to homogenize squeezing data. Squeezing tests for the cell CT23 were performed at $60 \mathrm{MPa}$. It is likely that a significant amount of water was squeezed during squeezing while only a small portion of ions were squeezed out. Squeezing data are systematically lower than inferred AET data because the solutions squeezed out are diluted compared to porewater.

It is believed that inferred aqueous extract data are more likely to be less affected by artifacts than squeezing data.

Table 9 lists the inferred initial chemical composition of sample 4.1 (see Fig. 2) which has a gravimetric water content of $25.7 \%$. The geochemical model used to infer the chemical composition of this sample 4.1 assumes that the sample contains no gypsum. The geochemical model reproduces 
all measured data except bicarbonate. The amount of sulphate minerals after 183 days of heating and hydration changes due to mineral dissolution/precipitation because the gravimetric water contents of compacted bentonite in the cell CT23 increase reaching values up to $33 \%$.

The THMC model was used to quantify the dissolution/precipitation of gypsum and anhydrite in bentonite samples due to heating and hydration. Gypsum is the stable phase in ambient conditions while anhydrite is more stable for temperatures above $43{ }^{\circ} \mathrm{C}$. Heating and hydration of the cell CT23 started at ambient conditions. Therefore, initially all the solid sulphate is present as gypsum.

Fig. 8 and 9 show the spatial distribution of the volume fractions of gypsum and anhydrite calculated with the THMC model, respectively. Gypsum dissolves initially everywhere in the cell because the initial porewater is unsaturated with respect to gypsum (Fig. 8). Later, gypsum dissolution is affected by the combination of two fronts which migrate in opposite directions: 1) The hydration front which moves inwards into the cell and 2) The thermal front which moves away from the heater and induces the conversion of gypsum to anhydrite. Such fronts meet after about 15 days at a distance of $2.5 \mathrm{~cm}$ from the hydration boundary. Fig. 8 shows the distribution of volume fraction of gypsum after 10 days just soon before both fronts meet. The rise of temperature induced by the heater causes the conversion of gypsum to anhydrite. At $t=0.004$ days, the temperature near the heater has already increased enough so that all gypsum has been converted to anhydrite. Almost all gypsum in sections 1 to 4 has been converted to anhydrite once temperature has reached steady conditions after 1 day (Fig. 8 and 9). After 1 day, gypsum in the section 5 is dissolved due to the inflow of hydration water and it is exhausted after about 15 days while anhydrite precipitates in sections 1 to 4 and especially near the heater due to evaporation. At later times, anhydrite dissolves also as the hydration proceeds from section 5 to section 1 . At the end of the experiment, precipitated anhydrite remains only in section 1 near the heater (Fig. 10). A large amount of anhydrite is 
observed near the heater due to evaporation. There is a zone $(0.13<\mathrm{z}<0.14)$ where anhydrite is entirely dissolved due to vapour condensation.

Temperature decreases during the cooling stage when the heater is switched off. This induces the conversion of anhydrite to gypsum in section 1 (Fig. 11).

Values of precipitated gypsum computed with the THMC model in Fig. 11 were used for the inference of the porewater chemical composition from aqueous extract data with the inverse method of Zheng et al. (2008a). The volume fraction of gypsum for section 1 is $0.23 \%$ while that for the rest of the sections is zero. The initial volume fraction of anhydrite is zero everywhere. When gypsum is considered in the geochemical model for the interpretation of aqueous extract data of sections 2 to 5 , computed results agree poorly with measured aqueous extract data. Fernández et al. (2001) encountered a similar problem and proposed that the plausible reason could be the existence of stagnant zones which could reduce the effective 'chemical' porosity for sulphate.

5.4. Testing computed concentrations with inferred concentrations from AET

Model testing and validation is usually performed by comparing model results to measured data. The difficulties in obtaining directly the porewater chemistry pose a grand challenge for testing the model of the cell CT23. Model testing is performed by the following stages: 1) S1: heating and hydration of the bentonite block for 183 days; 2) S2: switching off the heater, cooling of the bentonite block for 0.12 days and cutting the block into slices; and 3) S3: conducting aqueous extract tests by mixing bentonite samples obtained in S2 with water and measuring the concentrations of major ions in the aqueous extracts. These concentrations are denoted here as "measured data". The THMC model simulates stages S1 and S2 and calculates the concentration of major ions corresponding to step S2 and the mineral volume fraction after sample cooling S2. The inverse model of Zheng et al. (2008a) is used to estimate the concentrations of major ions at S2 which are denoted here as "inferred aqueous extract data" from measured data at stage S3. The 
mineral volume fraction at stage S2 which is needed as an input for the inverse model is calculated with the THMC model.

Fig. 12 to Fig. 20 show the model results after 183.13 days for $\mathrm{Cl}^{-}, \mathrm{Ca}^{2+}, \mathrm{Mg}^{2+}, \mathrm{Na}^{+}, \mathrm{K}^{+} \mathrm{SO}_{4}{ }^{2-}$, $\mathrm{HCO}_{3}{ }^{-}$, and $\mathrm{pH}$. Model results are compared to inferred aqueous extract data. Measured data by squeezing and aqueous extract tests are also shown in these figures. Fig. 12 shows the computed spatial distribution of $\mathrm{Cl}^{-}$concentrations at different times. Hydration causes dilution which induces a decrease in the concentration of dissolved $\mathrm{Cl}^{-}$near the inflow boundary (left part of Fig. 12) while the concentration increases near the heater due to the evaporation of bentonite porewater near the heater (right part of Fig. 12). The effective diffusion coefficient for compacted bentonite was estimated from $\mathrm{Cl}^{-}$inferred aqueous extract data. Its optimum value is equal to $9.2 \times 10^{-11} \mathrm{~m}^{2} / \mathrm{s}$. Fig. 13 shows the comparison of computed spatial distribution of $\mathrm{Cl}^{-}$concentration and inferred aqueous extract data at the end of the experiment. Computed $\mathrm{Cl}^{-}$concentrations reproduce the trend of inferred aqueous extract data.

Dissolved cations $\mathrm{Ca}^{2+}, \mathrm{Mg}^{2+}, \mathrm{Na}^{+}$and $\mathrm{K}^{+}$show trends similar to those of $\mathrm{Cl}^{-}$. These species are subjected to dilution and evaporation processes as well as mineral dissolution/precipitation and cation exchange. In general, concentrations increase from the hydration side to the heater. Computed calcium concentrations generally agree with inferred aqueous extract data except near the hydration boundary where the $\mathrm{Ca}^{2+}$ measured aqueous extract data in section 5 are larger than those in sections 2, 3 and 4 (see Figure 14) due to a sampling artifact caused by colloidal particles which were not sufficiently filtered during sampling preparation (ENRESA 2006a; Samper et al. 2008a).

Computed $\mathrm{Mg}^{2+}$ concentrations slightly underestimate inferred aqueous extract data (Fig. 15). Although equilibrium with dolomite could improve the fit to $\mathrm{Mg}^{2+}$ data, our geochemical model does not consider dolomite because it is not supported by other geochemical data (ENRESA, 
2006b). The possibility of kinetically controlled dolomite dissolution-precipitation, however, cannot be ruled out.

Computed $\mathrm{Na}^{+}$concentrations agree acceptably well with inferred aqueous extract data (Fig. 16). In a similar manner, computed $\mathrm{K}^{+}$concentrations fit well inferred aqueous extract data except for the data near the hydration boundary which may be affected by a sampling artifact (Fig. 17).

Computed sulphate concentrations reproduce the general trend of inferred aqueous extract data, but clearly underestimate the inferred data located at the middle of the cell (Fig. 18). This figure shows also the results of a sensitivity run performed with the THMC model in which the initial volume fraction of gypsum is equal to zero. Clearly, model results of the sensitivity run are significantly worse than those of the reference model which does consider an initial amount of gypsum. This result is consistent with the findings of Fernández et al. (2001) which show that gypsum plays a role in controlling the chemistry of sulphate in FEBEX bentonite.

Fig. 19 shows the computed spatial distribution of bicarbonate concentrations at the end of experiment. Computed results reproduce the general trend of inferred aqueous extract data except for the sample near the hydration boundary in section 5. It should be noticed that the measured aqueous extract of $\mathrm{Ca}^{2+}$ in section 5 is much larger than those of sections 3 and 4 (Fig. 14), but these three sections have similar measured $\mathrm{HCO}_{3}{ }^{-}$and $\mathrm{pH}$. We recall here that inferred $\mathrm{HCO}_{3}{ }^{-}$aqueous extract concentrations are not estimated independently, but derived from equilibrium with respect to calcite. Therefore, a too large $\mathrm{Ca}^{2+}$ inferred aqueous extract concentration in section 5 leads to a too small $\mathrm{HCO}_{3}{ }^{-}$inferred aqueous extract concentration.

The computed spatial distribution of $\mathrm{pH}$ reproduces aqueous extract and squeezing data (Fig. 20). The fact that $\mathrm{pH}$ values measured with both experimental techniques are similar together with the uniform spatial distribution of $\mathrm{pH}$ throughout the cell attests that bentonite has a large buffering capacity. Fig. 20 shows also the computed $\mathrm{pH}$ in a sensitivity run in which protonation/deprotonation by surface complexation is neglected. Clearly, surface complexation 
plays a major role in controlling $\mathrm{pH}$ of bentonite porewater. Inferred $\mathrm{pH}$ is clearly overestimated when surface complexation is ignored because calcite dissolves near the hydration boundary and leads to a too high $\mathrm{pH}$ while calcite precipitates near the heater and provokes a decrease of $\mathrm{pH}$ (Fig. 20).

\subsection{Model uncertainties}

There are uncertainties in the initial chemical composition of bentonite porewater. To study the effect of the initial concentration on the distribution of chemical species at the end of the experiment, a sensitivity run was performed using the initial concentrations derived by Samper et al. (2008a) from squeezing data, denoted here as $C_{s q}^{i}$. Model results of the sensitivity run are compared with those of the base run in which initial concentrations were derived from aqueous extract data, $C_{a q}^{i}$. Values of $C_{s q}^{i}$ and $C_{a q}^{i}$ are listed in Table 5. The largest differences in initial concentrations occur for $\mathrm{SO}_{4}{ }^{2-}$ and $\mathrm{Ca}^{2+}$. Model results for $\mathrm{SO}_{4}{ }^{2-}, \mathrm{HCO}_{3}{ }^{-}, \mathrm{Ca}^{2+}, \mathrm{Mg}^{2+}$ and $\mathrm{Na}^{+}$are shown in Fig. 14 to 21. Clearly, concentrations are sensitive to initial concentrations. The largest differences in computed concentrations are observed for $\mathrm{Ca}^{2+}$ (Fig. 14) and $\mathrm{Mg}^{2+}$ (Fig. 15) near the hydration boundary and for $\mathrm{HCO}_{3}^{-}$near the heater (Fig. 19). Computed concentrations with the initial concentrations derived from aqueous extract data squeezing data, $C_{a q}^{i}$, fit inferred aqueous extract data better than the model based on $C_{s q}^{i}$ while computed concentrations with the initial concentrations derived from squeezing data, $C_{s q}^{i}$, fit squeezing data better than the model based on $C_{a q}^{i}$ because $C_{s q}^{i}$ and the measured squeezing data suffer from similar disturbing effects and limitations (Sacchi et al., 2001).

Cation exchange has a significant effect on the evolution of major cations. Hydration water which is more diluted than initial bentonite porewater causes calcite dissolution and the concentration of dissolved $\mathrm{Ca}^{+2}$ increases. Consequently dissolved $\mathrm{Ca}^{+2}$ exchanges with exchanged $\mathrm{Na}^{+}$and aqueous $\mathrm{Na}^{+}$increases. Cation exchange acts in essence as a sink for aqueous $\mathrm{Ca}^{+2}$ and a 
source for aqueous $\mathrm{Na}^{+}$. The concentration of aqueous $\mathrm{Na}^{+}$computed with a model without cation exchange reactions is smaller than that of the base run near the hydration side where calcite dissolution is more significant (Figure 16). On the contrary, concentrations of aqueous $\mathrm{Ca}^{+2}$ in the run without cation exchange are larger than those of the base run (Figure 14). The effect of cation exchange reactions on $\mathrm{K}^{+}$is similar to that on $\mathrm{Na}^{+}$while cation exchange has an effect on $\mathrm{Mg}^{+2}$ similar to that on $\mathrm{Ca}^{+2}$ (not shown here).

High temperatures close to the heater may cause $\mathrm{CO}_{2(\mathrm{~g})}$ degassing from liquid water. Such $\mathrm{CO}_{2(\mathrm{~g})}$ will transport through the gas phase and eventually redissolve in the liquid water again when it reaches the condensation zone. $\mathrm{CO}_{2(\mathrm{~g})}$ degassing and dissolution will affect $\mathrm{pH}$, dissolved $\mathrm{HCO}_{3}{ }^{-}$ and calcite dissolution and precipitation. The current model which does not account for $\mathrm{CO}_{2(\mathrm{~g})}$ degassing and dissolution could be improved by considering such processes.

As suggested by one of the reviewers, an additional sensitivity run was conducted by prescribing the temperature to values equal to those measured in the cell (Figure 5) to evaluate the sensitivity of computed concentrations to changes in temperatures throughout the cell. It was found that the change in the spatial distribution of temperatures changes the evaporation/condensation pattern and consequently affects the distribution of both conservative and reactive species. Therefore, uncertainties in computed temperatures may affect significantly the distribution of chemical species. Consequently, reproducing properly the temperatures is crucial for modelling heating and hydration experiments.

There are uncertainties on the quantity of gypsum available for dissolution and its dissolution mechanism (kinetics or local equilibrium). Computed results agree poorly with measured aqueous extract data when gypsum is considered in the geochemical model for the interpretation of aqueous extract data. Future studies should address the issue of available gypsum and the relevance of kinetic gypsum dissolution/precipitation. Gases were considered neither in the geochemical model of the cell CT23 nor in the interpretation of aqueous extract data. While the assumption of closed 
system may represent well the conditions of the cell CT23, this assumption may not be valid for the aqueous extraction tests which were performed in open atmospheric conditions.

The THMC model presented here is valid for a single porosity medium and disregards deviatory stress components. It could be improved by considering a dual continuum model with macro and micro pores (see Samper et al., 2008b) and accounting for deviatory components.

The model predicts an increase of concentrations towards the heater for all species except for $\mathrm{HCO}_{3}{ }^{-}$. Inferred aqueous extract data of some chemical species such as $\mathrm{Cl}^{-}, \mathrm{Ca}^{2+}$ and $\mathrm{Mg}^{2+}$ increase near the heater while those of $\mathrm{K}^{+}, \mathrm{Na}^{+}$and $\mathrm{SO}_{4}{ }^{2-}$ remain constant. The model reproduces the behaviour of the data near the heater for $\mathrm{HCO}_{3}{ }^{-}, \mathrm{Cl}^{-}, \mathrm{Ca}^{2+}$ and $\mathrm{Mg}^{2+}$ but not for $\mathrm{K}^{+}, \mathrm{Na}^{+}$and $\mathrm{SO}_{4}{ }^{2-}$ which remain constant. This discrepancy of the model cannot be overcome by calibrating the solute diffusion coefficient. Samper et al. (2008a) also found a similar model deviation for the FEBEX in situ test. This deviation which could be caused by the transient precipitation of some salts at the heater-bentonite interface should be analyzed in future studies.

\section{Conclusions}

The strong interplays between thermal $(\mathrm{T})$, hydrodynamic $(\mathrm{H})$, mechanical $(\mathrm{M})$ and chemical (C) processes during the hydration stage of a repository require the use of coupled THMC models. Models for non-isothermal multiphase flow and multicomponent reactive solute transport in deformable porous medium have been presented. In addition to standard solute transport and geochemical processes, these models consider solute cross diffusion, thermal and chemical osmosis and account for bentonite swelling with a state-surface approach. The capabilities of these THMC models have been tested with the numerical model of the cell CT23 heating and hydration experiment performed on a sample of compacted FEBEX bentonite. Thermal, hydrodynamic and mechanical parameters have been calibrated with transient temperatures and final water content and porosity data. The results of the hydrodynamic model reveals that: 1) Chemical osmosis can be 
safely disregarded for compacted FEBEX bentonite because chemical osmotic suction accounts for less than $1 \%$ of the total matrix suction and 2) Thermal osmosis could be relevant during heating and hydration of bentonite. The estimated thermo-osmotic permeability for the cell CT23 is equal to $4.2 \times 10^{-13} \mathrm{~m}^{2} / \mathrm{K} / \mathrm{s}$. The reactive transport model has been calibrated with porewater chemical data derived from aqueous extract data. Dilution and evaporation are the main processes controlling the concentration of conservative species. Dissolved cations are mostly affected by calcite dissolutionprecipitation and cation exchange reactions. Dissolved sulfate is controlled by gypsum/anhydrite dissolution-precipitation. $\mathrm{pH}$ is mostly buffered by protonation/deprotonation via surface complexation. In general, computed concentrations agree well with inferred aqueous extract data at all sections except section 5 near the hydration boundary where measured aqueous extract data for dissolved cations may be affected by a sampling artifact. The fit of $\mathrm{Cl}^{-}$data is excellent except for the data near the heater. The largest deviations of the model from inferred aqueous extract data occur for dissolved $\mathrm{SO}_{4}{ }^{2-}$ which is underpredicted by the model.

\section{Acknowledgements}

This research was performed within the framework of the FEBEX project funded by ENRESA and European Union through contracts FI4W-CT95-0006 and FIKW-CT-2000-00016 of the Nuclear Fission Program. Partial funding was provided also by the Spanish Ministry of Science and Technology (CICYT, CGL2006-09080) and University of La Coruña through a research scholarship awarded to the first author. We are grateful to the Associate Editor, Carles Ayora, Tianfu $\mathrm{Xu}$ and two other anonymous reviewers for comments and recommendations which improved the paper. This work was also partially supported by the U.S. Department of Energy and LBNL under Contract No. DE-AC02-05CH11231.

\section{References}

Alonso E. and A. Ledesma, Editors, 2005, Advances in Understanding Engineered Clay Barriers, A. Balkema Pub., Leiden, 583 pp. 
Alonso, E.E., Gens, A. and Josa, A., 1990. A constitutive model for partially saturated soils. Géotechnique, 40(3): 405-430.

Alonso, E.E., Vaunat, J. and Gens, A., 1999. Modelling the mechanical behaviour of expansive clays. Engineering Geology, 54: 173-183.

Bradbury, M.H. and Baeyens, B., 1997. A mechanistic description of Ni and Zn sorption on Namontmorillonite. Part II: Modelling. J. Contaminant Hydrology, 27: 223-248.

Bradbury, M.H. and Baeyens, B., 1998. A physicochemical characterisation and geochemical modelling approach for determining pore water chemistries in argillaceous rocks. Geochim. Cosmochim. Acta, 62: 783-795.

Bradbury, B. and Baeyens, B., 2003. Pore water chemistry in compacted resaturated MX-80 bentonite. J. Contaminant Hydrology, 61: 329-338.

Cuevas, J., Villar, M., Fernández, A., Gómez, P. and Martín, P., 1997. Pore waters extracted from compacted bentonite subjected to simultaneous heating and hydration. Applied Geochemistry, 12: 473-481.

Chijimatsu M, L Börgesson, T Fujita, P. Jussila, S Nguyen, J Rutqvist and L Jing, 2009, Model development and calibration for the coupled thermal, hydraulic and mechanical phenomena of the bentonite, Environ Geol 57:1255-1261, DOI 10.1007/s00254-008-1401-2.

Dai Z \& J Samper, 2004, Inverse problem of multicomponent reactive chemical transport in porous media: Formulation and Applications Wat Resour Res, Vol 40, W07407, doi:10.1029/2004WR003248.

Dai Z., Samper, J., 2006. Inverse modeling of water flow and multicomponent reactive transport in coastal aquifer systems. J. of Hydrol. Vol. 327, Issues 3-4, 447-461.

Dai Z., Samper J., Ritzi, R., 2006. Identifying geochemical processes by inverse modeling of multicomponent reactive transport in Aquia aquifer, Geosphere, Vol. 4, № 4, 210-219.

Dai, Z., J. Samper, A. Wolfsberg, \& D. Levitt, 2008, Identification of relative conductivity models for water flow and solute transport in unsaturated compacted bentonite. Physics and Chemistry of the Earth, Vol. 33, S177-S185. doi:10.1016/j.pce.2008.10.012.

De Vries, D.A., 1963. Thermal properties of soils. In: Van Wijk, W.R. (Ed.), Physics of Plant Environment. North-Holland Publishing Company, Amsterdam, pp. 210-235.

Eching, S.O., Hopmans, J.W. and Wallender, W.W., 1994. Estimation of in situ unsaturated soil hydraulic functions from scaled cumulative drainage data. Water Resour. Res., 30(8): 23872394. 
European Commission (EC), 2000. Full-scale engineered barriers experiment for a deep geological repository in crystalline host rock (FEBEX Project), Report of the European Commission, EUR 19147 EN. 403 pp.

ENRESA, 2006a. FEBEX: Updated final report. ENRESA Tech. Publ. PT 05-0/2006, 589 pp.

ENRESA, 2006b. FEBEX: Final THG modelling report. ENRESA Tech. Publ. PT 05-3/2006, 155 pp.

Fernández, A., J Cuevas, and P Rivas 2001. Pore water chemistry of the FEBEX bentonite. Mat. Res. Soc. Symp. Proc., 663: 573-588.

Fernández, A.M., B Baeyens, M Bradbury and P Rivas, 2004. Analysis of the pore water chemical composition of a Spanish compacted bentonite used in an engineered barrier. Physics and Chemistry of the Earth, 29(1): 105-118

Fredlund, DG. and H Rahardjo, 1993, Soil Mechanics for Unsaturated Soils, Wiley-IEEE, 517 pp.

Galíndez, J.,M., J. Molinero, J. Samper and C.B Yang, 2006, Simulating concrete degradation processes by reactive transport models, J. Phys. IV France, Vol. 136, 177-188.

García-Ruiz, JM, R Villasuso, C Ayora, A Canals and F Otálora, 2007 Formation of natural gypsum megacrystals in Naica, Mexico, Geology, v 35; no. 4; 327-330; doi: 10.1130/G23393A.1.

Gens, A. and Alonso, E.E., 1992. A framework for the behaviour of unsaturated expansive clays. Canadian Geotechnical Journal, 29: 1013-1032.

Ghassemi, A. and Diek, A., 2002. Porothermoelasticity for swelling shales. Journal of Petroleum Science and Engineering, 34: 123-125.

Guimarães, L.D., Gens, A. and Olivella, S. 2007. Coupled thermo-hydro-mechanical and chemical analysis of expansive clay subjected to heating and hydration. Transport in Porous Media, 66 (3): 341-372.

Inoue, M., Simunek, J., Hopmans, W. and Clausnitzer, V., 1998. In situ estimation of soil hydraulic functions using a multistep soil-water extraction technique. Water Resour. Res., 34(5): 1035-1055.

Juncosa, R., 2001. Modelos de fujo multifásico no isotermo y de transporte reactivo multicomponente en medios porosos. Ph.D Dissertation, Universidad Politécnica Madrid, Madrid, 287 pp. . [in Spanish].

Keijzer, T.J.S., Kleingeld, P.J. and J.P.G., L., 1999. Chemical osmosis in compacted clayey material and the prediction of water transport. Engineering geology, 53: 151-159. 
Keijzer, T.J.S. and Loch, J.P.G., 2001. Chemical osmosis in compacted dredging sludge. Soil Sci. Soc. Am. J., 65: 1045-1055.

Komine, H. and Ogata, N., 1996. Prediction for swelling characteristics of compacted bentonite. Canadian Geotechnical Journal, 33: 11-22.

Komine, H. and Ogata, N., 2003. New equations for swelling characteristics of bentonite-based buffer materials. Canadian Geotechnical Journal, 40: 460-475.

Lichtner, P.C., 1996. Continuum formulation of multicomponent-multiphase reactive transport. In: P.C. Lichtner, Steefel, C. I., and Oelkers, E. H. (Editor), Reviews in Mineralogy. Reactive Transport in Porous Media. Mineralogical Society of America, Washington, DC.

Lloret, A. and Alonso, E.E., 1995. State surfaces for partially saturated soils, Proceedings of the International Conference on Soils Mechanics and Foundation Engineering, Balkema, pp. $557-562$.

Molinero J., Samper, J., 2004, Groundwater Flow and Solute Transport in Fracture Zones: An Improved Model for a Large-Scale Field Experiment at Äspö (Sweden), J. Hydraulic Research. Vol. 42, 2004, Extra Issue, 157-172.

Molinero, J., Samper, J., 2006. Modeling of reactive solute transport in fracture zones of granitic bedrocks. J. Cont. Hydrol., 82, 293-318.

Molinero, J., Samper, J., Yang, C., Zhang, G., 2004. Biogeochemical reactive transport model of the Redox zone experiment of the Äspö hard rock laboratory (Sweden). Nuclear Technology $48(2), 151-165$.

Navarro, V. and Alonso, E.E., 2000. Modelling swelling soils for disposal barriers. Computers and Geotechnics, 27: 19-43.

Nguyen, T.S., Selvadurai, A.P.S. and Armand, G., 2005. Modelling the FEBEX THM experiment using a state surface approach. International Journal of Rock Mechanics and Mining Science, 42(5-6): 639-651.

Olivella, S., Gens, A., Carrera, J. and Alonso, E.E., 1996. Numerical formulation for a simulator (CODE_BRIGHT) for the coupled analysis of saline media. Engineering Computations, 13(7): 87-112.

Pan, L. and Wu, L., 1998. A hybrid global optimization method for inverse estimation of hydraulic parameters: Annealing-simplex method. Water Resour. Res., 34(9): 2261-2269.

Parkhurst, D. L., and C. A. J. Appelo (1999), User's guide to PHREEQC (version 2)—A computer program for speciation, batch-reaction, onedimensional transport, and inverse geochemical calculations, U.S. Geol. Surv. Water-Resour. Invest. Rep., 99-4259, 312 pp. 
Pollock, D.W., 1986. Simulation of fluid flow and energy transport processes associated with highlevel radioactive waste disposal in unsaturated alluvium, Water Resour. Res., 22 (5), 765-775.

Saaltink, M.W., Batlle, F., Ayora, C., Carrera, J. and Olivella, S., 2004. RETRASO, a code for modelling reactive transport in saturated and unsaturated porous media. Geologica Acta, 2(3): $235-251$.

Sacchi, E., Michelot, J.L., Pitsch, H., Lalieux, P. and Aranyossy, J.F., 2001. Extraction of water and solution from argillaceous rock for geochemical characterisation: Methods, processes, and current understanding. Hydrogeology Journal, 9: 17-33.

Samper, J., Juncosa, R., Delgado, J. and Montenegro, L., 2000. CORE ${ }^{2 \mathrm{D}}$ : A code for non-isothermal water flow and reactive solute transport, Users manual version 2, Technical Publ. ENRESA, 6/2000, Madrid, $131 \mathrm{pp}$.

Samper, J., T. Xu and C. Yang, 2009. A sequential partly iterative approach for multicomponent reactive transport with $\mathrm{CORE}^{2 \mathrm{D}}$, Comput Geosci, DOI 10.1007/s10596-008-9119-5.

Samper, J., Zhang, G., Montenegro, L., 2006. Coupled microbial and geochemical reactive transport models in porous media: Formulation and Application to Synthetic and In Situ Experiments, Journal of Iberian Geology, Vol 32(2), 211-217.

Samper J., Yang, C., 2006, Stochastic Analysis of Transport and Multicomponent Competitive Monovalent Cation Exchange in Aquifers, Geosphere, April, Vol. 2, 102-112.

Samper J., L. Zheng, L. Montenegro, A.M. Fernández, \& P. Rivas, 2008a, Testing coupled thermohydro-chemical models of compacted bentonite after dismantling the FEBEX in situ test, Appl Geochem, Vol 23/5: 1186-1201. doi:10.1016/j.apgeochem.2007.11.010.

Samper, J., L. Zheng, A.M. Fernández and L. Montenegro, 2008b, Inverse modeling of multicomponent reactive transport through single and dual porosity media, J Cont Hydrol, 10.1016/j.jconhyd.2008.03.008.

Samper, J., C. Lu, \& L. Montenegro, 2008c, Coupled hydrogeochemical calculations of the interactions of corrosion products and bentonite, Physics and Chemistry of the Earth, Vol.

33. Supplement 1, S306-S316. doi:10.1016/j.pce.2008.10.009

Sánchez, M., A Gens, LJDN Guimarães, and S Olivella, 2005. A double structure generalized plasticity model for expansive materials. International Journal for Numerical and Analytical Methods in Geomechanics, 29: 751-787.

Šimunek, J. and van Genuchten, M.T., 1996. Estimating unsaturated soil hydraulic properties from tension disc infiltrometer data by numerical inversion. Water Resour. Res., 32(9): 26832696. 
Soler, J.M., 2001. The effect of coupled transport phenomena in the Opalinus Clay and implications for radionuclide transport. Journal of Contaminant Hydrology, 53: 63-84.

Steefel, C.I., 2001. GIMRT, Version 1.2: Software for Modelling multicomponent, multidimensional reactive transport. Users Guide. Technical Report UCRL-MA-143182, Lawrence Livermore National Laboratory, Livermore, California.

Sun, N Z, 1994. Inverse Problems in Groundwater Modelling. Kluwer Academic Publishers, the Netherland, $364 \mathrm{pp}$.

Tang AM, Cui YJ, Le TT, 2008, A study on the thermal conductivity of compacted bentonites, Applied Clay Science, 41(3-4), 181-189

Tebes-Stevens, C.L., Espinoza, F. and Valocchi, A.J., 2001. Evaluating the sensitivity of a subsurface multicomponent reactive transport model with respect to transport and reaction parameters. J. Contaminant Hydrology, 52: 3-27.

Thomas, H.R. and He, Y., 1998. Modelling the behaviour of unsaturated soil using an elastoplastic constitutive model. Géotechnique, 48(5): 589-603.

Thomas, H.R. and Cleall, P.J., 1999. Inclusion of expansive clay behaviour in coupled thermo hydraulic mechanical models. Engineering Geology, 54: 93-108.

Villar, M.V., Sánchez, M., Gens, A., 2008. Behaviour of a bentonite barrier in the laboratory: experimental results up to 8 years and numerical simulation. Physics and Chemistry of the Earth, Vol. 33, Supplement 1, pp. S476-S485.

White, A.F., 1995. Multiphase nonisothermal transport of systems of reactive chemicals. Water Resour. Res., 31(7): 1761-1772.

Wolery, T.J., 1992. EQ3/6. A software Package for Geochemical modelling of Aqueous Systems: Package Overview and Installation Guide Version 7.0. UCRL-MA-110662-PT-I, Lawrance Livermore National Laboratory, Livermore, California.

Xie, M., Agus, S.S., Schanz, T. and Kolditz, O., 2004. An upscaling method and a numerical analysis of swelling/shrinking processes in a compacted bentonite/sand mixture. International Journal for Numerical and Analytical Methods in Geomechanics, 28: 14791502.

Xie, M., Bauer, S., Kolditz, O., Nowak, T. and Shao, H., 2006. Numerical simulation of reactive processes in an experiment with partially saturated bentonite. J. Contaminant Hydrology, 83: 122-147.

$\mathrm{Xu}$, T. and Pruess, K., 1998. Coupled modelling of non-isothermal multi-phase flow, solute transport and reactive chemistry in porous and fractured media: 1. Model development and 
validation. Report LBNL-42050, Lawrence Berkeley National Laboratory, Berkeley, California.

Xu, T., J. Samper, C. Ayora, M. Manzano \& E. Custodio, 1999, Modeling of non-isothermal multicomponent reactive transport in field scale porous media flow systems, J Hydrol. Vol.: 214 (1-4), 144-164.

Yang C, J Samper, J Molinero and M Bonilla, 2007, Modelling geochemical and microbial consumption of dissolved oxygen after backfilling a high level radioactive waste repository, J Cont Hydrol, 93 130-148.

Yang, C., J. Samper, \& L. Montenegro, 2008, A coupled non-isothermal reactive transport model for long-term geochemical evolution of a HLW repository in clay, Environmental Geology, 53:1627-1638. DOI 10.1007/s00254-007-0770-2.

Zhang G, J. Samper \& L. Montenegro, 2008, Coupled thermo-hydro-bio-geochemical reactive transport model of the CERBERUS heating and radiation experiment in Boom clay, Appl Geochem, Vol 23/4: 932-949. doi:10.1016/j.apgeochem.2007.09.010.

Zheng, L. and J. Samper, 2008, Coupled THMC model of FEBEX mock-up test, Physics and Chemistry of the Earth, Physics and Chemistry of the Earth, Vol. 33, S486-S498. doi:10.1016/j.pce.2008.10.023.

Zheng, L., J. Samper, and L. Montenegro 2008a, Inverse hydrochemical models of aqueous extract experiments, Physics and Chemistry of the Earth, Vol. 33 Issues 12-13: 1009-1018. doi:10.1016/j.pce.2008.05.012.

Zheng, L., J. Samper, L. Montenegro \& J.C. Mayor, 2008b, Flow and reactive transport model of a ventilation experiment in Opallinus clay, Physics and Chemistry of the Earth, Vol. 33. Issues 14-16, 1009-1018. doi:10.1016/j.pce.2008.05.012

Zhou, Y., Rajapakse, R.K.N.D. and Graham, J., 1999. Coupled Field in a deformable unsaturated medium. International Journal of Solid and Structures, 36: 4841-4868. 


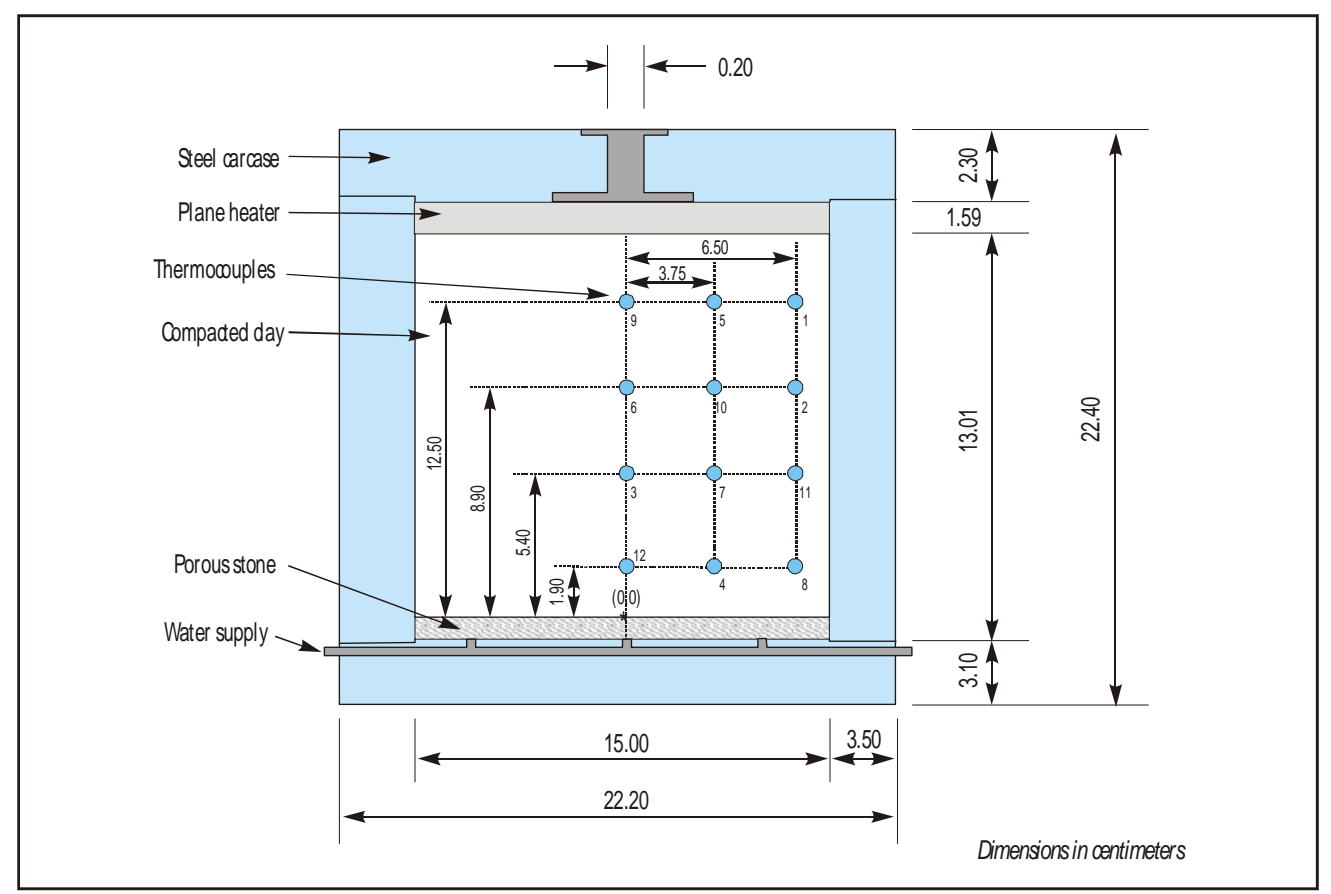

Figure 1. Schematic design of the heating and hydration laboratory experiment in the cell CT23 (ENRESA, 2006a).

\begin{tabular}{|c|c|c|c|c|}
\hline \multicolumn{4}{|c|}{ Plane heater } & \\
\hline Section 1 & 1.3 & 1.2 & 1.1 & $\{1.83 \mathrm{~cm}$ \\
\hline Section 2 & 23 & 2.2 & 21 & $\int 3.00 \mathrm{~cm}$ \\
\hline Section 3 & 3.3 & 3.2 & 3.1 & $3.00 \mathrm{~m}$ \\
\hline Section 4 & 4.3 & 4.2 & 4.1 & $3.00 \mathrm{~mm}$ \\
\hline Section 5 & 5.3 & 5.2 & 5.1 & $\uparrow^{3.00 \mathrm{~mm}}$ \\
\hline \multicolumn{4}{|c|}{ Hydration supply } & \\
\hline
\end{tabular}

Figure 2. Scheme of the bentonite sampling after heating and hydration of the cell CT23 for porewater analysis by squeezing (a) and physical and geochemical characterization of the solid phase by aqueous extracts (b). 


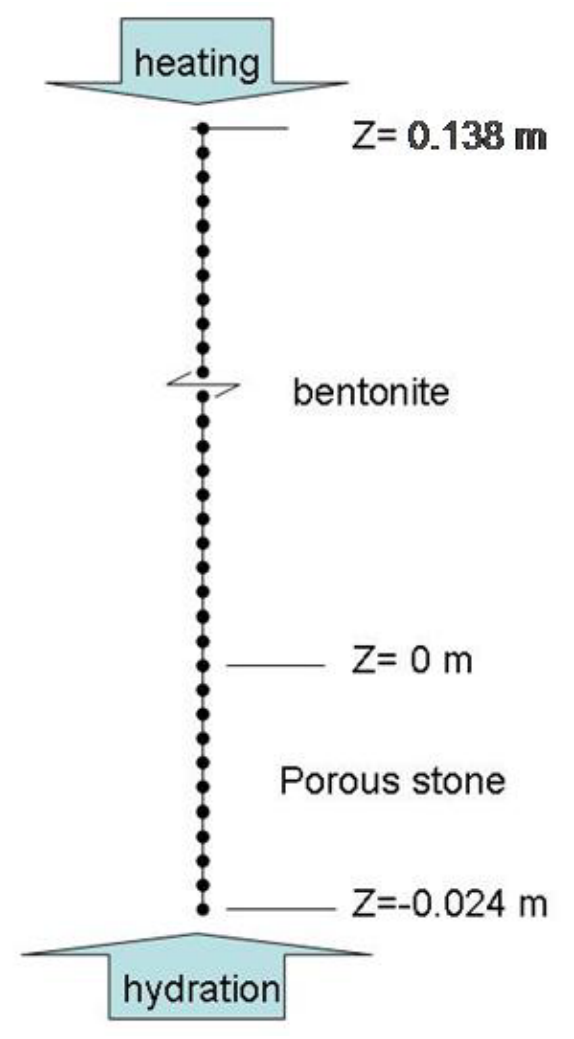

Figure 3. One dimensional finite element mesh used for the THMC model of the cell CT23.

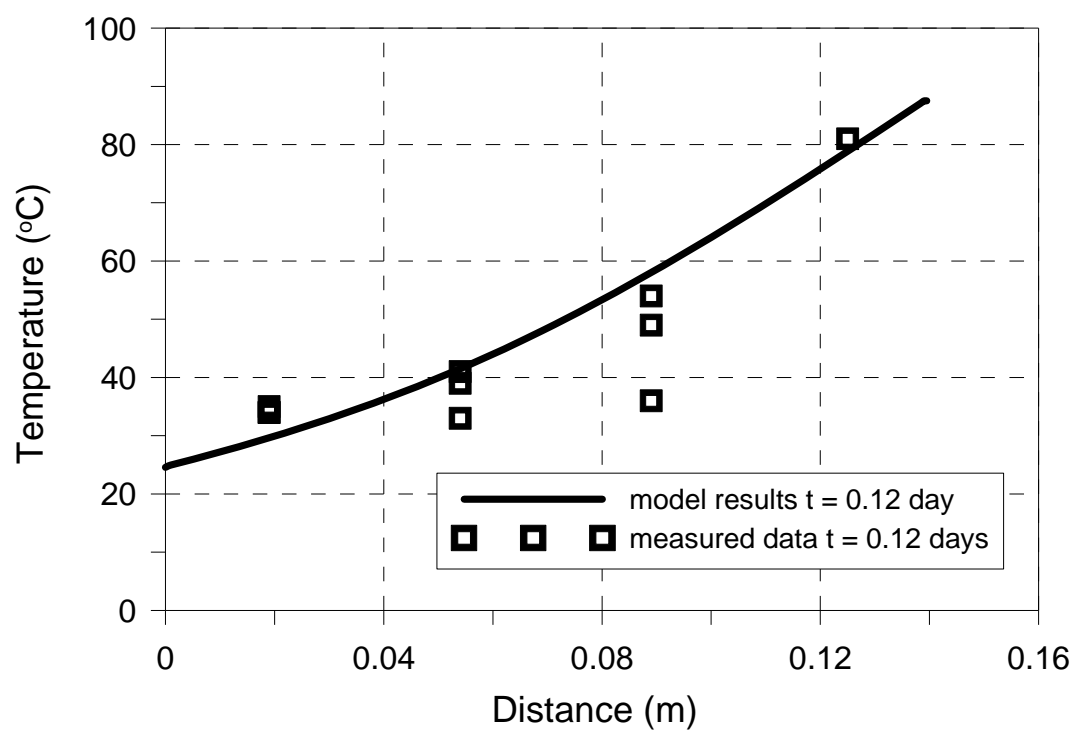

Figure 4. Spatial distribution of measured (symbols) and computed temperature (line) at $\mathrm{t}=0.12$ days. 


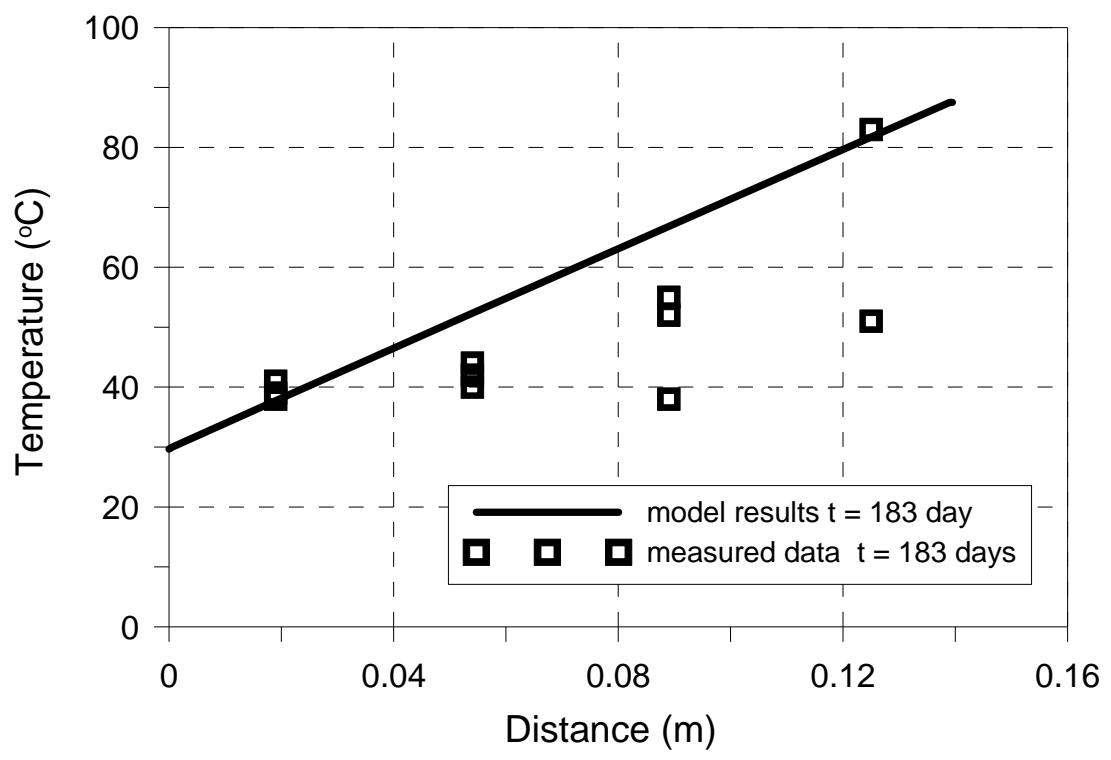

Figure 5. Comparison of computed (lines) and measured (symbols) temperatures at the end of the heating and hydration $(\mathrm{t}=183$ days $)$.

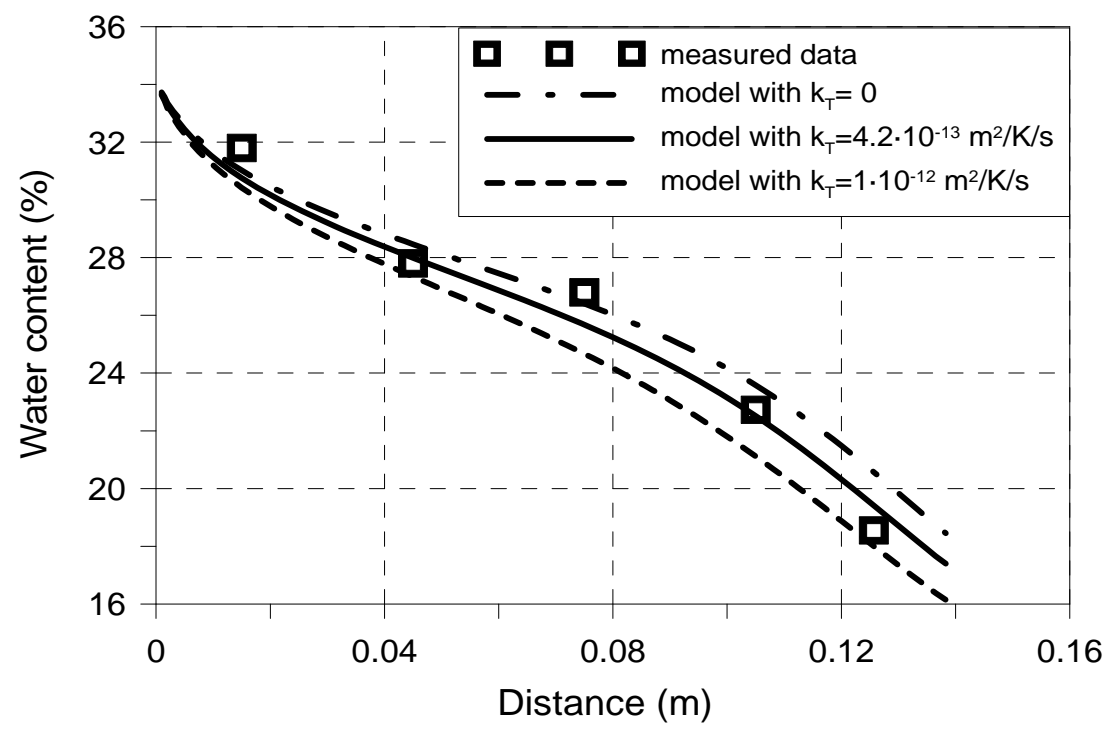

Figure 6. Comparison of computed (symbol) and measured (line) gravimetric water content at the end of the heating and hydration ( $\mathrm{t}=183$ days) for different values of the thermo-osmotic permeability, $k_{T}$. 


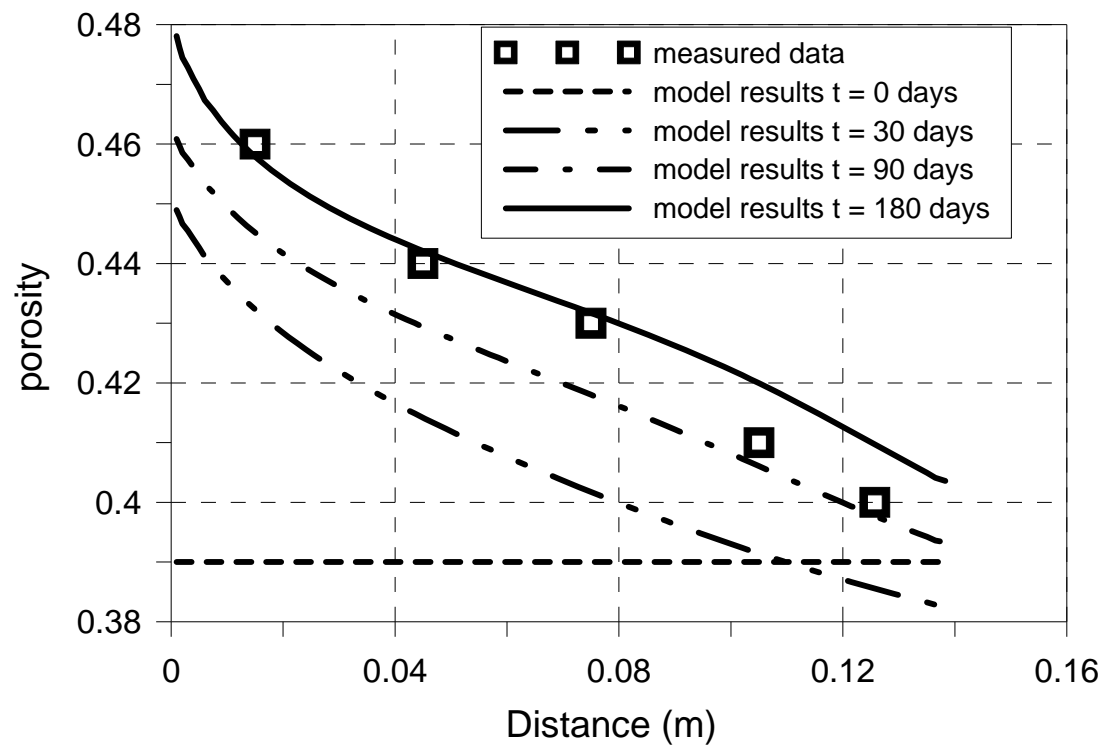

Figure 7. Comparison of computed (symbols) and measured (lines) porosity at the end of the heating and hydration $(\mathrm{t}=183$ days $)$

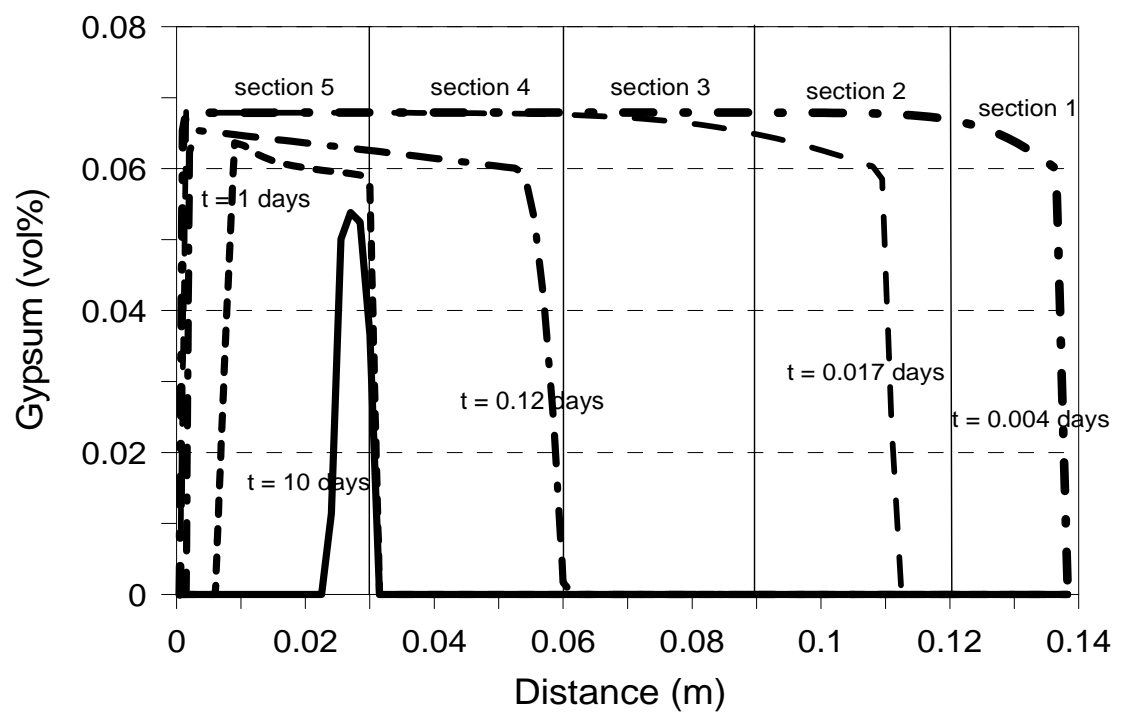

Figure 8. Computed spatial distribution of the volume fraction of gypsum at different times. 


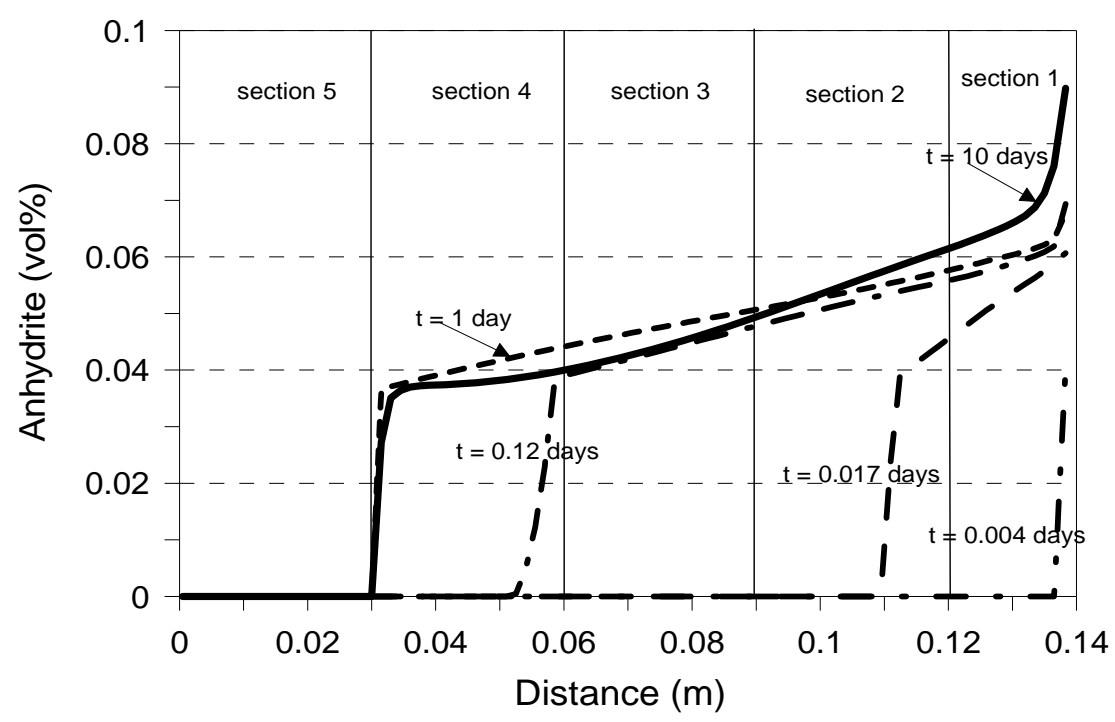

Figure 9. Computed spatial distribution of the volume fraction of anhydrite at different times.

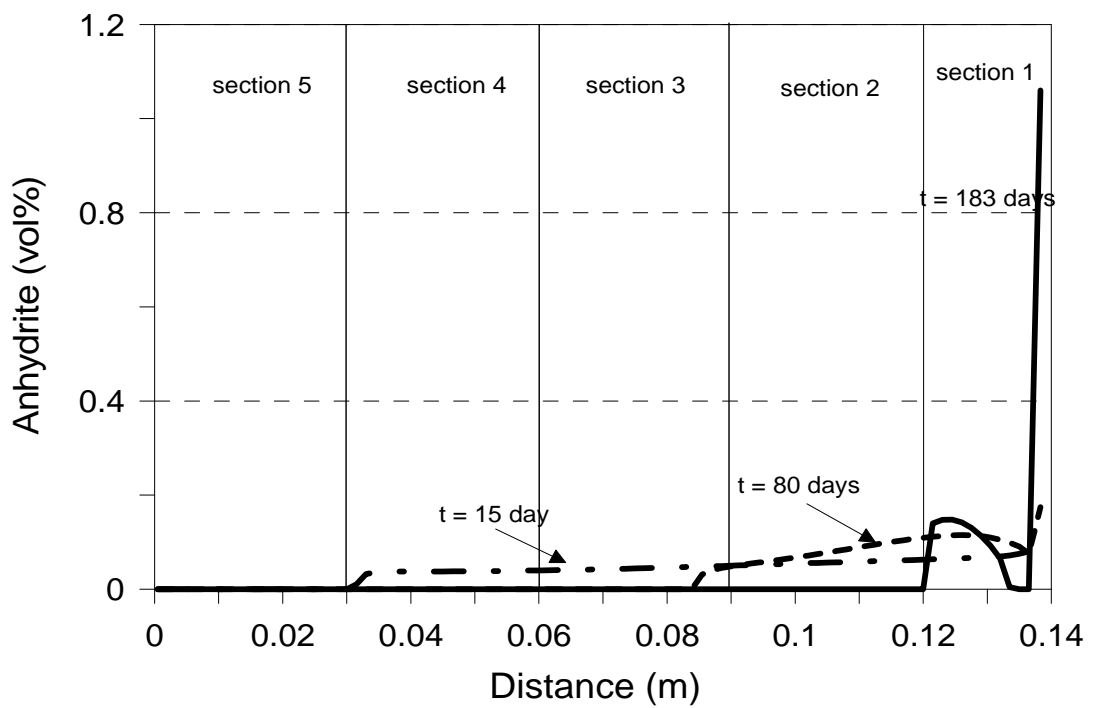

Figure 10. Computed spatial distribution of the volume fraction of anhydrite at different times. 


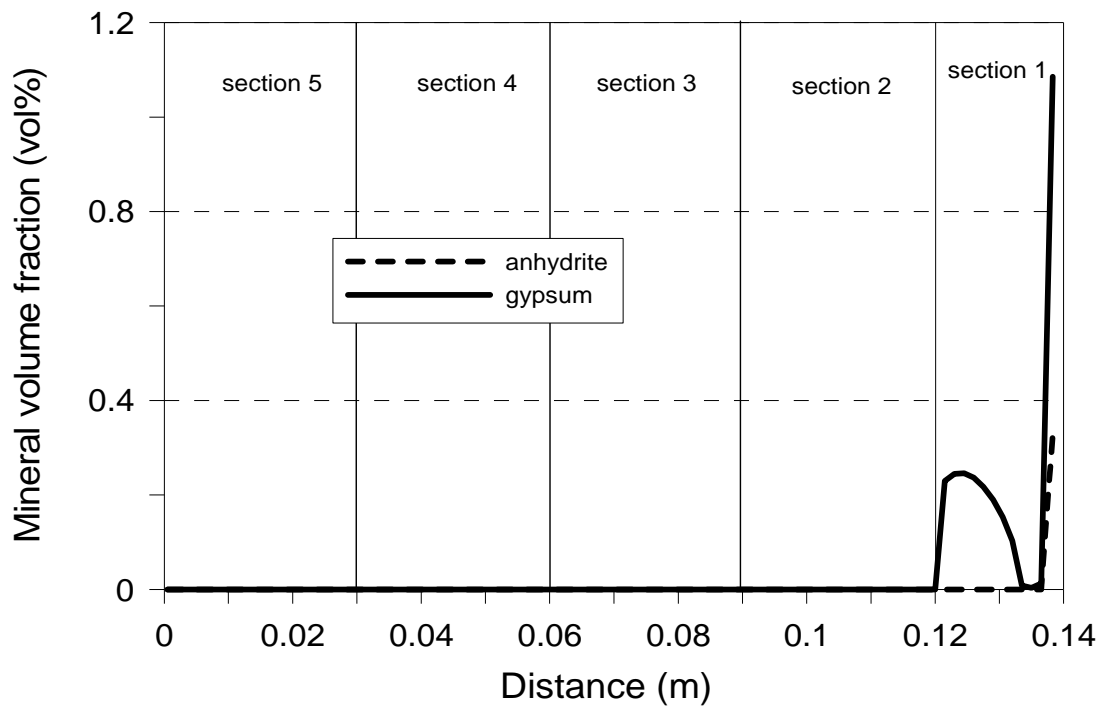

Figure 11. Computed spatial distribution of the volume fraction of anhydrite and gypsum after cooling.

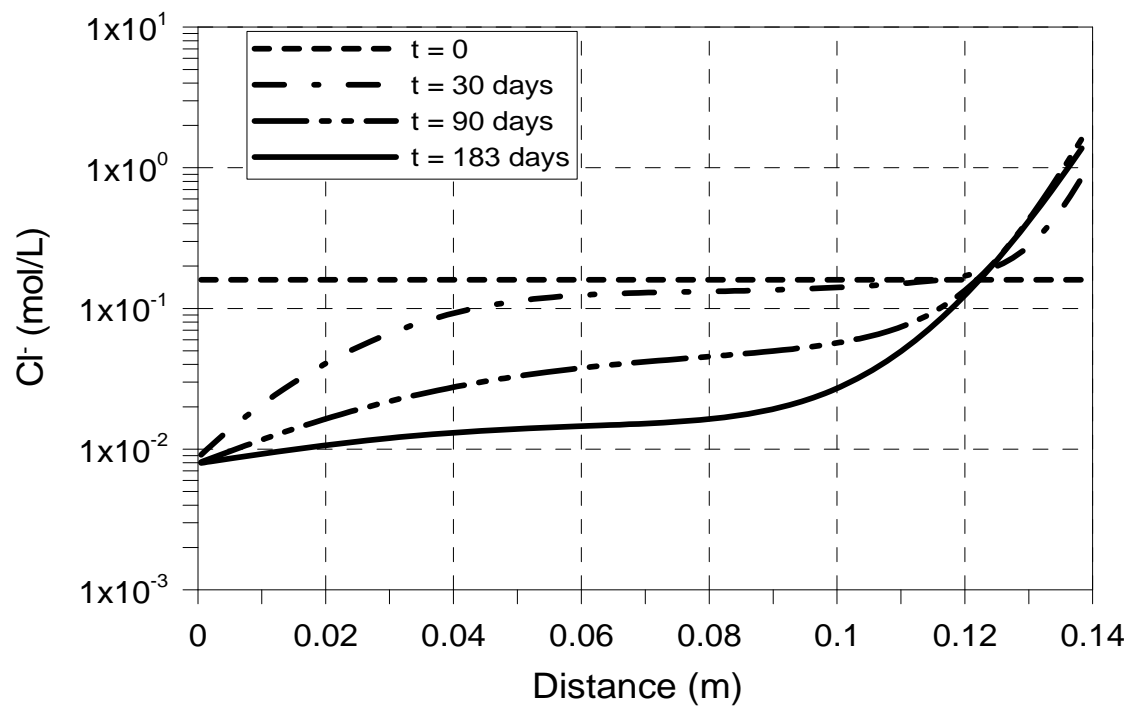

Figure 12. Computed spatial distribution of computed $\mathrm{Cl}^{-}$concentrations at different times. 


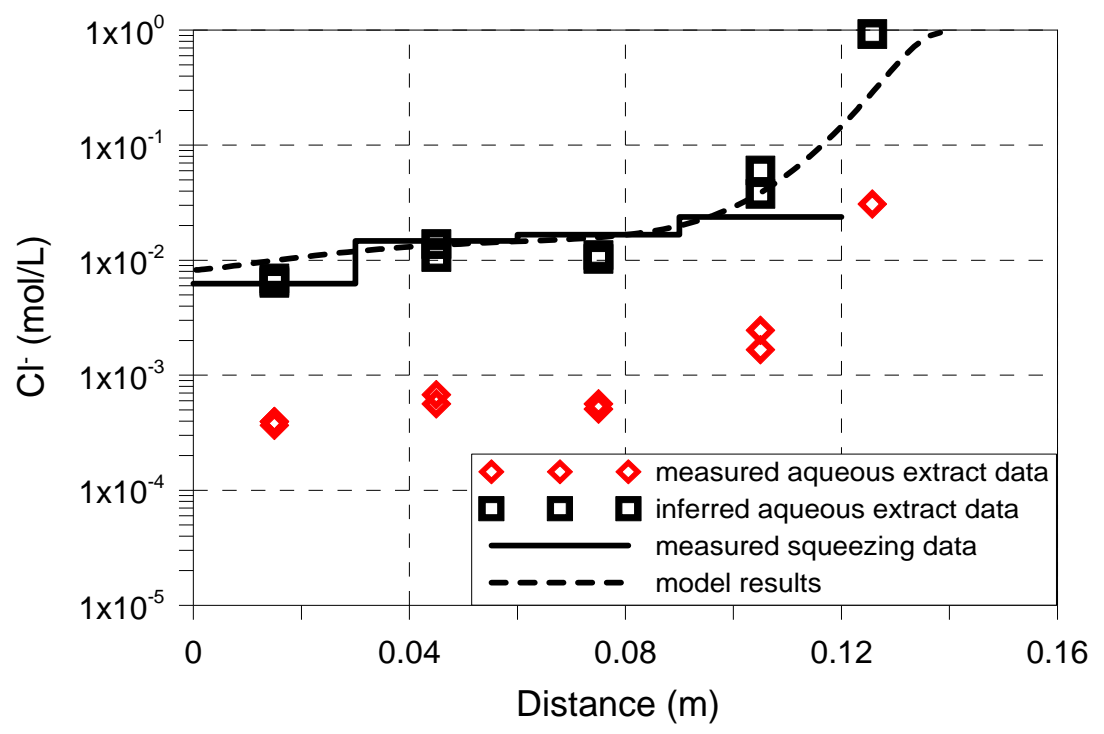

Figure 13. Comparison of computed $\mathrm{Cl}^{-}$concentrations and inferred aqueous extract data at the end of the experiment $(t=183.13$ days $)$. Also shown are measured squeezing and aqueous extract data.

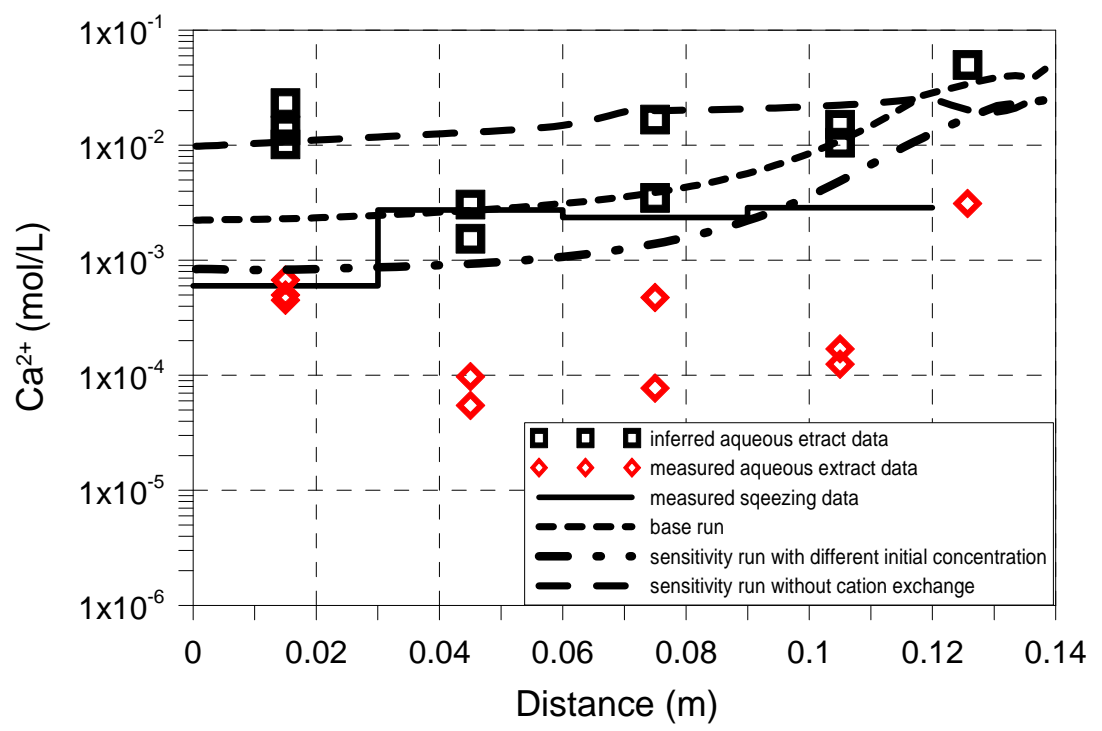

Figure 14. Comparison of computed $\mathrm{Ca}^{2+}$ concentrations and inferred aqueous extract data at the end of the experiment $(\mathrm{t}=183.13$ days $)$. Also shown are measured squeezing and aqueous extract data as well as the results of two sensitivity runs corresponding to: 1) a different initial concentration and 2) no cation exchange. 


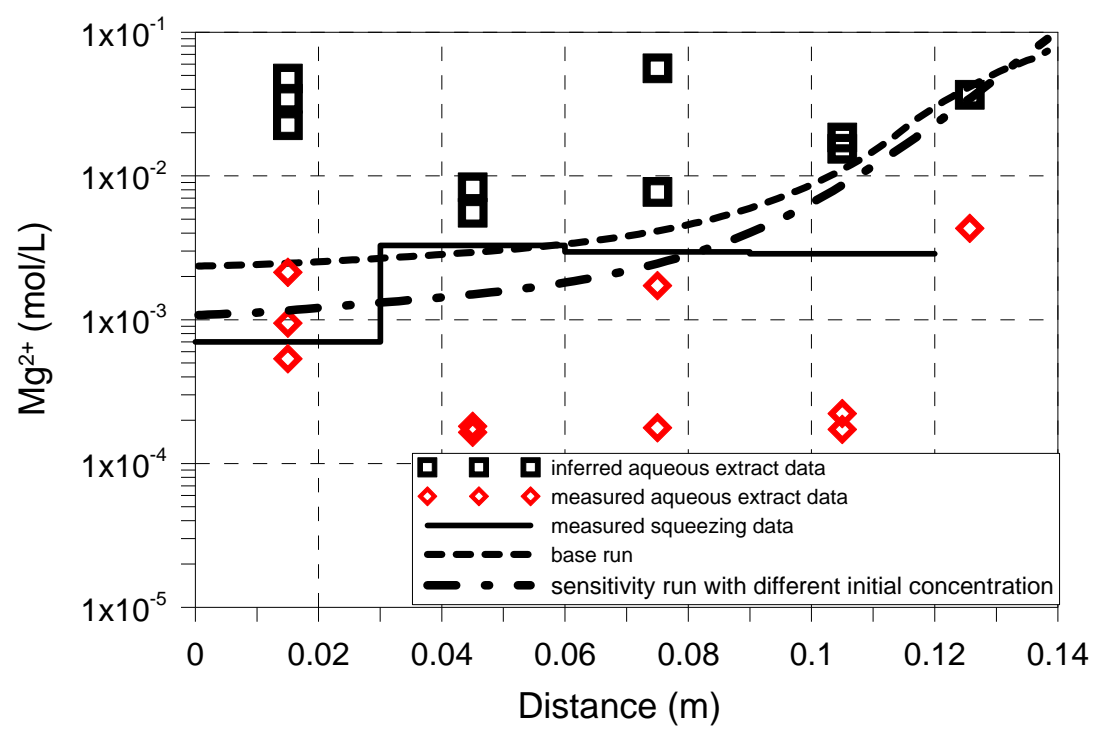

Figure 15. Comparison of computed $\mathrm{Mg}^{2+}$ concentrations and inferred aqueous extract data at the end of the experiment $(\mathrm{t}=183.13$ days). Also shown are measured squeezing and aqueous extract data as well as the results of a sensitivity run with a different initial concentration.

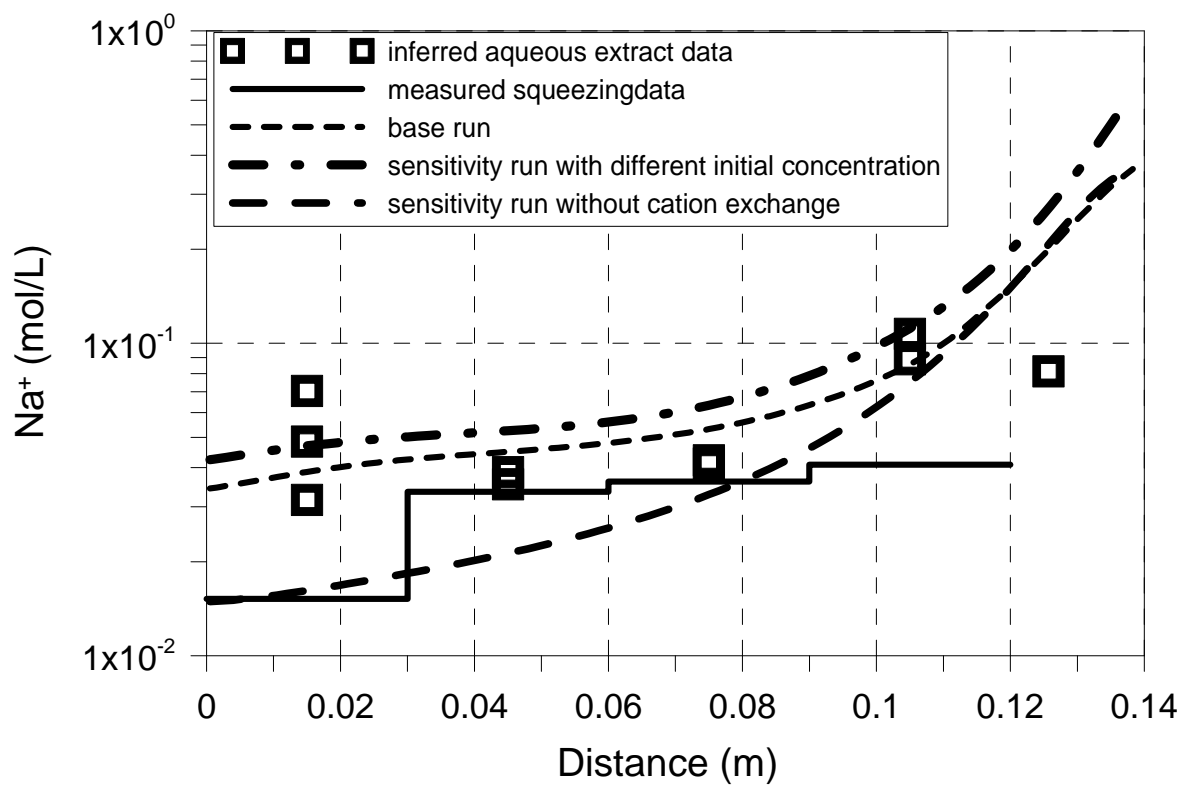

Figure 16. Comparison of computed $\mathrm{Na}^{+}$concentrations and inferred aqueous extract data at the end of the experiment $(\mathrm{t}=183.13$ days). Also shown are measured squeezing data and the results of a sensitivity run without cation exchange. 


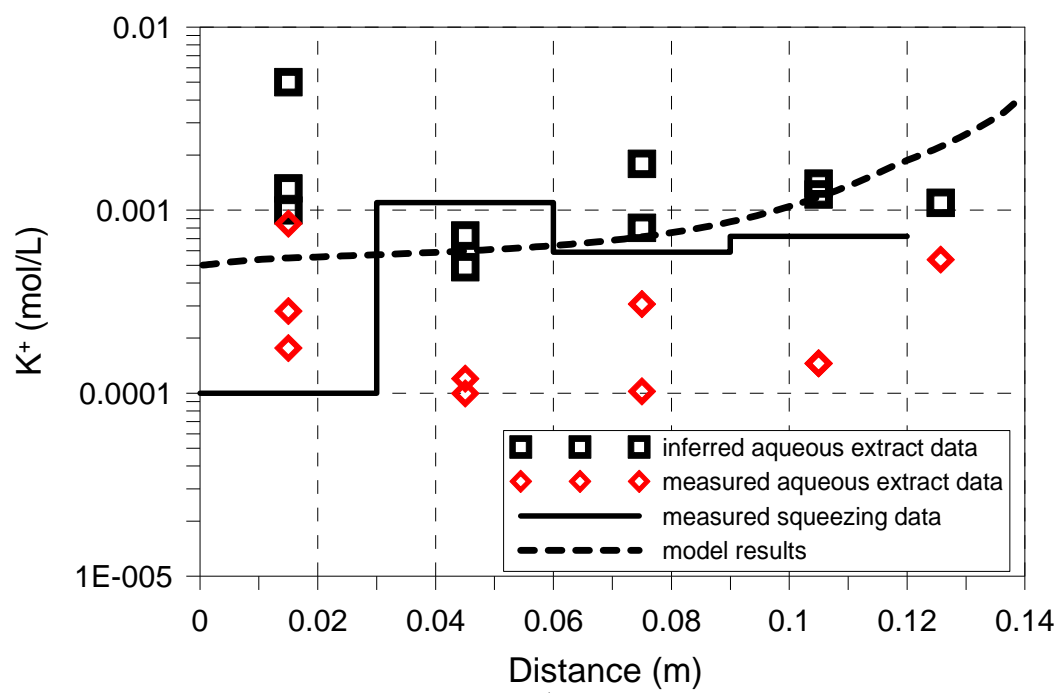

Figure 17. Comparison of computed $\mathrm{K}^{+}$concentrations and inferred aqueous extract data at the end of the experiment $(\mathrm{t}=183.13$ days $)$. Also shown are measured squeezing and aqueous extract data.

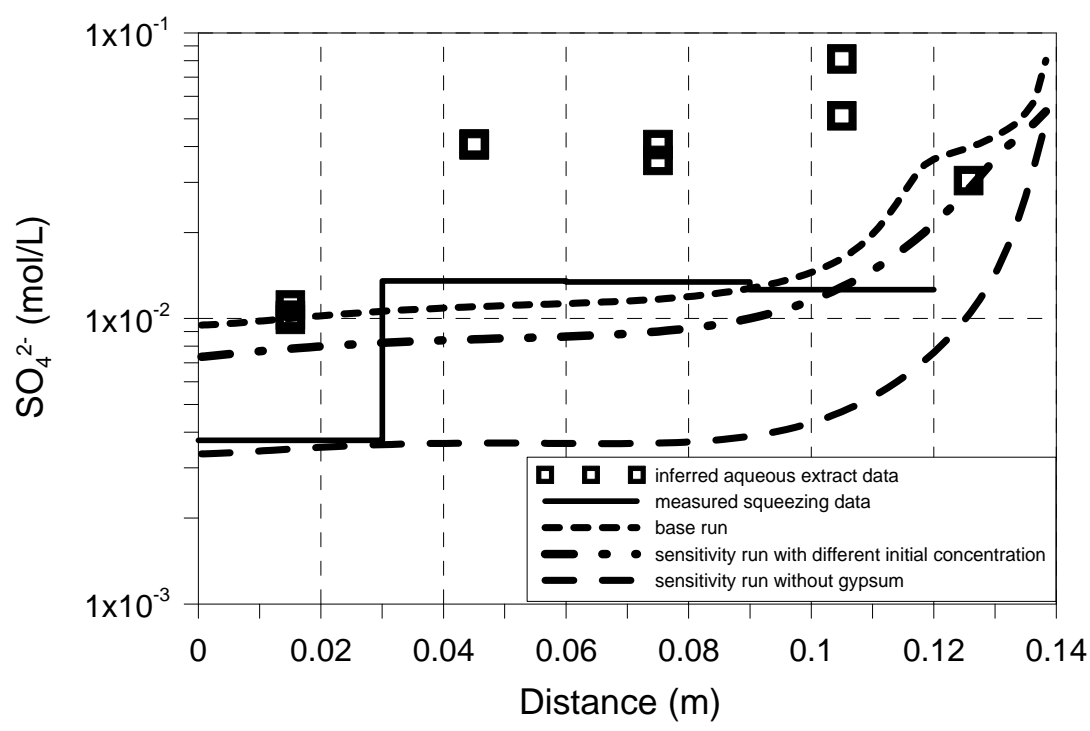

Figure 18.Comparison of computed $\mathrm{SO}_{4}{ }^{2-}$ concentrations and inferred aqueous extract data at the end of the experiment $(\mathrm{t}=183.13$ days), Also shown are measured squeezing data and model results of two sensitivity runs corresponding to: 1) No volume fraction of gypsum at $t=0 ; 2$ ) is zero, and 2) A different initial concentration. 


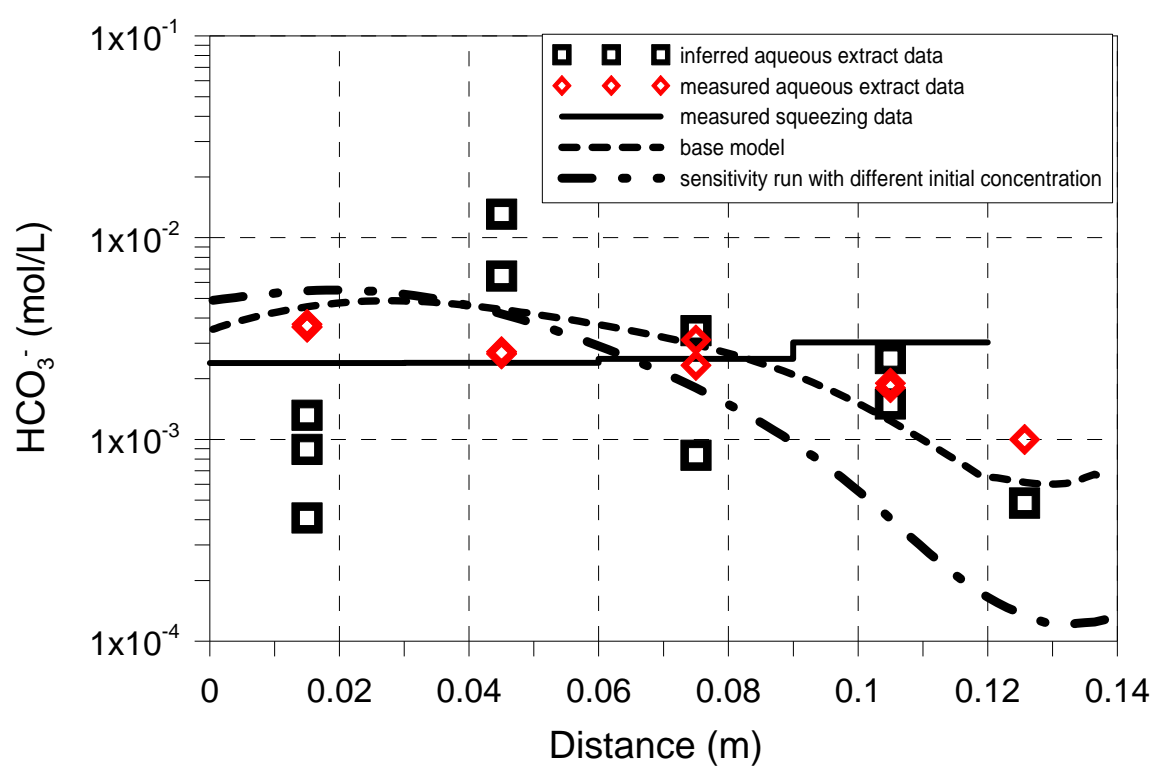

Figure 19. Comparison of computed $\mathrm{HCO}_{3}{ }^{-}$concentrations and inferred aqueous extract data at the end of the experiment $(\mathrm{t}=183.13$ days). Also shown are measured squeezing and aqueous extract data as well as the results of a sensitivity run with a different initial concentration.

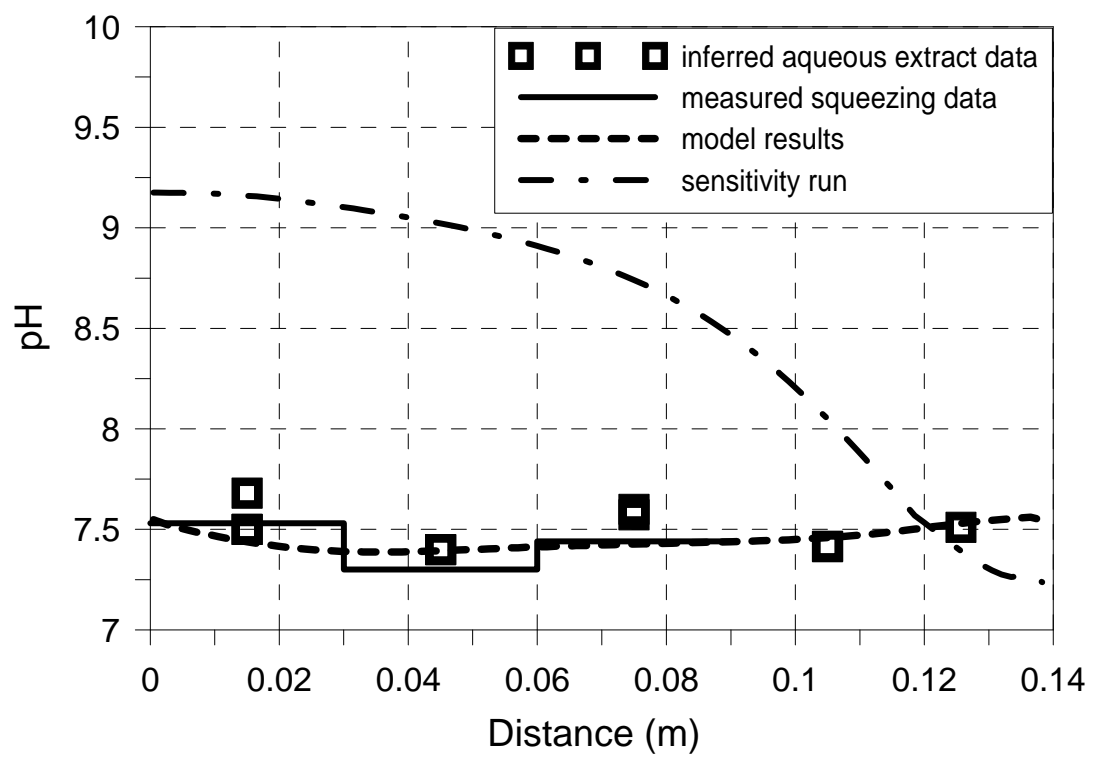

Figure 20. Comparison of computed $\mathrm{pH}$ and inferred aqueous extract data at the end of the experiment $(\mathrm{t}=$ 183.13 days). Also shown are measured squeezing data and model results of a sensitivity run without proton surface complexation reaction. 
Table 1. Equilibrium constants for aqueous complexes and minerals (Wolery, 1992), selectivity coefficients for cation exchange reactions (ENRESA, 2006b), and protolysis constants for surface complexation reactions (Bradbury and Baeyens, 1997) at $25^{\circ} \mathrm{C}$.

\begin{tabular}{|c|c|}
\hline Aqueous complexes & Log K at $25^{\circ} \mathrm{C}$ (Wolery, 1992) \\
\hline $\mathrm{CaCl}^{+} \Leftrightarrow \mathrm{Ca}^{2+}+\mathrm{Cl}^{-}$ & 0.70457 \\
\hline $\mathrm{CaCO}_{3}(\mathrm{aq})+\mathrm{H}^{+} \Leftrightarrow \mathrm{Ca}^{2+}+\mathrm{HCO}_{3}^{-}$ & 7.1009 \\
\hline $\mathrm{CaHCO}_{3}^{+} \Leftrightarrow \mathrm{Ca}^{2+}+\mathrm{HCO}_{3}^{-}$ & -1.04111 \\
\hline $\mathrm{CaSO}_{4}(\mathrm{aq}) \Leftrightarrow \mathrm{Ca}^{2+}+\mathrm{SO}_{4}^{2-}$ & -2.0855 \\
\hline $\mathrm{CO}_{2}(\mathrm{aq})+\mathrm{H}_{2} \mathrm{O} \Leftrightarrow \mathrm{H}^{+}+\mathrm{HCO}_{3}^{-}$ & -6.3733 \\
\hline $\mathrm{CO}_{3}^{2-}+\mathrm{H}^{+} \Leftrightarrow \mathrm{HCO}_{3}^{-}$ & 10.371 \\
\hline $\mathrm{H}_{3} \mathrm{SiO}_{4}^{-}+\mathrm{H}^{+} \Leftrightarrow 2 \mathrm{H}_{2} \mathrm{O}+\mathrm{SiO}_{2}(\mathrm{aq})$ & 9.8626 \\
\hline $\mathrm{KSO}_{4}^{-} \Leftrightarrow \mathrm{K}^{+}+\mathrm{SO}_{4}^{2-}$ & -0.86822 \\
\hline $\mathrm{MgCl}^{+} \Leftrightarrow \mathrm{Mg}^{2+}+\mathrm{Cl}^{-}$ & 0.13413 \\
\hline $\mathrm{MgCO}_{3}(\mathrm{aq}) \Leftrightarrow \mathrm{Mg}^{2+}+\mathrm{CO}_{3}{ }^{2-}$ & -7.428 \\
\hline $\mathrm{MgHCO}_{3}^{+} \Leftrightarrow \mathrm{Mg}^{2+}+\mathrm{HCO}_{3}^{-}$ & -1.0295 \\
\hline $\mathrm{MgSO}_{4}(\mathrm{aq}) \Leftrightarrow \mathrm{Mg}^{2+}+\mathrm{SO}_{4}^{2-}$ & -2.3228 \\
\hline $\mathrm{NaHCO}_{3}(\mathrm{aq}) \Leftrightarrow \mathrm{Na}^{+}+\mathrm{HCO}_{3}^{-}$ & -0.2118 \\
\hline $\mathrm{NaSO}_{4}^{-} \Leftrightarrow \mathrm{Na}^{+}+\mathrm{SO}_{4}^{2-}$ & -0.79855 \\
\hline $\mathrm{OH}^{-}+\mathrm{H}^{+} \Leftrightarrow \mathrm{H}_{2} \mathrm{O}$ & 14.16 \\
\hline Minerals & Log K (Wolery, 1992) \\
\hline $\mathrm{CaCO}_{3}(\mathrm{~s})+\mathrm{H}^{+} \Leftrightarrow \mathrm{Ca}^{2+}+\mathrm{HCO}_{3}^{-}$ & 1.9299 \\
\hline $\mathrm{CaSO}_{4}(\mathrm{~s}) \Leftrightarrow \mathrm{Ca}^{2+}+\mathrm{SO}_{4}^{2-}$ & -4.2451 \\
\hline $\mathrm{CaSO}_{4} \cdot 2 \mathrm{H}_{2} \mathrm{O}(\mathrm{s}) \Leftrightarrow \mathrm{Ca}^{2+}+\mathrm{SO}_{4}{ }^{2-}+2 \mathrm{H}_{2} \mathrm{O}$ & -4.4699 \\
\hline $\mathrm{SiO}_{2}(\mathrm{~s}) \Leftrightarrow \mathrm{SiO}_{2}(\mathrm{aq})$ & -3.8334 \\
\hline Cation exchange & $\mathrm{K}_{\text {Na-cation }}$ (ENRESA, 2006b) \\
\hline $\mathrm{Na}^{+}+\mathrm{X}-\mathrm{K} \Leftrightarrow \mathrm{K}^{+}+\mathrm{X}-\mathrm{Na}$ & 0.138 \\
\hline $\mathrm{Na}^{+}+0.5 \mathrm{X}_{2}-\mathrm{Ca} \Leftrightarrow 0.5 \mathrm{Ca}^{2+}+\mathrm{X}-\mathrm{Na}$ & 0.2942 \\
\hline $\mathrm{Na}^{+}+0.5 \mathrm{X}_{2}-\mathrm{Mg} \Leftrightarrow 0.5 \mathrm{Mg}^{2+}+\mathrm{X}-\mathrm{Na}$ & 0.2881 \\
\hline Surface complexation reactions & Log $K_{\text {int }}$ (Bradbury and Baeyens, 1997) \\
\hline$\equiv \mathrm{S}^{\mathrm{S}} \mathrm{OH}_{2}^{+} \Leftrightarrow \equiv \mathrm{S}^{\mathrm{S}} \mathrm{OH}+\mathrm{H}^{+}$ & -4.5 \\
\hline$\equiv \mathrm{S}^{\mathrm{S}} \mathrm{O}^{-} \Leftrightarrow \mathrm{S}^{\mathrm{S}} \mathrm{OH}-\mathrm{H}^{+}$ & 7.9 \\
\hline$\equiv \mathrm{S}^{\mathrm{W} 1} \mathrm{OH}_{2}^{+} \Leftrightarrow \equiv \mathrm{S}^{\mathrm{W} 1} \mathrm{OH}+\mathrm{H}^{+}$ & -4.5 \\
\hline$\equiv \mathrm{S}^{\mathrm{W} 1} \mathrm{O}^{-} \Leftrightarrow \equiv \mathrm{S}^{\mathrm{W} 1} \mathrm{OH}-\mathrm{H}^{+}$ & 7.9 \\
\hline$\equiv \mathrm{S}^{\mathrm{W} 2} \mathrm{OH}_{2}^{+} \Leftrightarrow \equiv \mathrm{S}^{\mathrm{W} 2} \mathrm{OH}+\mathrm{H}^{+}$ & -6.0 \\
\hline$\equiv \mathrm{S}^{\mathrm{W} 2} \mathrm{O}^{-} \Leftrightarrow \equiv \mathrm{S}^{\mathrm{W} 2} \mathrm{OH}-\mathrm{H}^{+}$ & 10.5 \\
\hline
\end{tabular}


Table 2. Water flow parameters (EC, 2000; Zheng and Samper, 2008)

\begin{tabular}{|c|c|}
\hline $\begin{array}{l}\text { Intrinsic permeability of liquid, } k^{i l}\left(\mathrm{~m}^{2}\right) \\
\text { as a function of porosity }\end{array}$ & $\begin{aligned} k^{i l}=k_{0} \frac{\phi^{3}}{(1-\phi)^{2}} \frac{\left(1-\phi_{0}\right)^{2}}{\phi_{0}^{3}} \\
\text { with } \phi_{0}=0.39 k_{0}=2.75 \cdot 10^{-21}\end{aligned}$ \\
\hline $\begin{array}{l}\text { Liquid relative permeability } k^{r l} \text { as a } \\
\text { function of liquid saturation } S_{l}\end{array}$ & $k^{r l}=S_{l}^{3}$ \\
\hline $\begin{array}{l}\text { Retention curve: liquid saturation } S_{l} \text { as a } \\
\text { function of suction } \Psi(\mathrm{Pa})\end{array}$ & $S_{1}=\frac{\left(1-9.1 \cdot 10^{-10} \psi\right)^{1.1}}{\left[\left(1+5 \cdot 10^{-8} \psi\right)^{1.22}\right]^{0.18}}$ \\
\hline $\begin{array}{c}\text { Liquid viscosity }(\mathrm{kg} / \mathrm{m} \cdot \mathrm{s}) \text { as a function of } \\
\text { temperature } T\left({ }^{\circ} \mathrm{C}\right)\end{array}$ & $0.6612(T-229)^{-1.562}$ \\
\hline $\begin{array}{l}\text { Liquid density }\left(\mathrm{kg} / \mathrm{m}^{3}\right) \text { as a function of } \\
\text { liquid pressure } p^{l} \text { and temperature } T\end{array}$ & $998.2 \cdot \mathrm{e}^{\left[5 \cdot 10^{-7}\left(\mathrm{p}^{1}-100\right)-2.1 \cdot 10^{-4}\left(\mathrm{~T}-\mathrm{T}_{\text {ref }}\right)\right]}$ \\
\hline Reference temperature, $T_{\text {ref }}\left({ }^{\circ} \mathrm{C}\right)$ & 12 \\
\hline Gas intrinsic permeability $\left(\mathrm{m}^{2}\right)$ & $5 \cdot 10^{-10}$ \\
\hline Gas relative permeability $k^{r g}$ & $k^{r g}=\left(1-S_{l}\right)^{3}$ \\
\hline Vapour tortuosity & 0.3 \\
\hline Gas viscosity $(\mathrm{kg} / \mathrm{m} \cdot \mathrm{s})$ & $1.76 \cdot 10^{-5}$ \\
\hline Solid density $\left(\mathrm{kg} / \mathrm{m}^{3}\right)$ & $2780 \cdot \mathrm{e}^{\left[-2 \cdot 10^{-6}\left(\mathrm{~T}-\mathrm{T}_{\text {ref }}\right)\right]}$ \\
\hline $\begin{array}{l}\text { Reflection coefficient for chemical } \\
\text { osmosis }\end{array}$ & 0.2 \\
\hline
\end{tabular}

Table 3. Thermal parameters (EC, 2000; ENRESA, 2006b; Zheng and Samper, 2008)

\begin{tabular}{|c|c|}
\hline Specific heat of liquid $\left(\mathrm{J} / \mathrm{kg} \cdot{ }^{\circ} \mathrm{C}\right)$ & 4202 \\
\hline Specific heat of air $\left(\mathrm{J} / \mathrm{kg} \cdot{ }^{\circ} \mathrm{C}\right)$ & 1000 \\
\hline Specific heat of vapour $\left(\mathrm{J} / \mathrm{kg} \cdot{ }^{\circ} \mathrm{C}\right)$ & 1620 \\
\hline Specific heat of solid $\left(\mathrm{J} / \mathrm{kg} \cdot{ }^{\circ} \mathrm{C}\right)$ & 835.5 \\
\hline Reference temperature $\left({ }^{\circ} \mathrm{C}\right)$ & 12 \\
\hline Thermal conductivity of liquid $\left(\mathrm{W} / \mathrm{m}^{\cdot{ }^{\circ} \mathrm{C}}\right)$ & 1.5 \\
\hline Thermal conductivity of air $\left(\mathrm{W} / \mathrm{m} \cdot{ }^{\circ} \mathrm{C}\right)$ & $2.6 \times 10^{-2}$ \\
\hline $\begin{array}{l}\text { Thermal conductivity of vapour } \\
\qquad\left(\mathrm{W} / \mathrm{m} \cdot{ }^{\circ} \mathrm{C}\right)\end{array}$ & $4.2 \times 10^{-2}$ \\
\hline Thermal conductivity of solid $\left(\mathrm{W} / \mathrm{m} \cdot{ }^{\circ} \mathrm{C}\right)$ & 1.23 \\
\hline Vaporization enthalpy $(\mathrm{J} / \mathrm{kg})$ & $2.45 \times 10^{6}$ \\
\hline
\end{tabular}


Table 4. Solute transport parameters (ENRESA, 2006b; Zheng and Samper, 2008).

\begin{tabular}{|c|c|}
\hline $\begin{array}{c}\text { Molecular diffusion coefficient in water } \\
D_{0}(T) \text { in } \mathrm{m}^{2} / \mathrm{s} \text { as a function of } T \text { and the } \\
\text { molecular diffusion coefficient at the } \\
\text { reference temperature } T_{r e f}\left({ }^{\circ} \mathrm{C}\right), D_{0}\left(T_{\text {ref }}\right)\end{array}$ & $D_{0}(T)=D_{0}\left(T_{r e f}\right) \frac{T}{T_{0}} \frac{\mu^{l 0}}{\mu^{l}}$ with $D_{0}\left(T_{r e f}\right)=2 \times 10^{-10}$ \\
\hline Longitudinal dispersivity (m) & 0.001 \\
\hline $\begin{array}{c}\text { Solute tortuosity } \tau \text { as a function of } \\
\text { volumetric water content } \theta \text { and porosity } \phi\end{array}$ & $\tau=\frac{\theta^{1 / 3}}{\phi^{2}}$ \\
\hline
\end{tabular}

Table 5. FEBEX bentonite porewater composition (mol/L) at water content of $13.3 \%$ estimated by Fernández et al. (2001) from aqueous extract data and Zheng and Samper (2008) from squeezing data.

\begin{tabular}{ccccccccc}
\hline Component & $\mathrm{Cl}^{-}$ & $\mathrm{SO}_{4}{ }^{2-}$ & $\mathrm{HCO}_{3}^{-}$ & $\mathrm{Ca}^{2+}$ & $\mathrm{Mg}^{2+}$ & $\mathrm{Na}^{+}$ & $\mathrm{K}^{+}$ & $\mathrm{pH}$ \\
\hline $\begin{array}{c}\text { Fernández et al } \\
\text { (2001) }\end{array}$ & $1.6 \times 10^{-1}$ & $3.2 \times 10^{-2}$ & $5 \times 10^{-4}$ & $2.2 \times 10^{-2}$ & $2.3 \times 10^{-2}$ & $1.3 \times 10^{-1}$ & $1.7 \times 10^{-3}$ & 7.72 \\
\hline $\begin{array}{c}\text { Zheng and } \\
\text { Samper (2008) }\end{array}$ & $1.87 \times 10^{-1}$ & $2.12 \times 10^{-2}$ & $6.65 \times 10^{-4}$ & $1.14 \times 10^{-2}$ & $1.44 \times 10^{-2}$ & $1.88 \times 10^{-1}$ & $1.68 \times 10^{-3}$ & 7.86 \\
\hline
\end{tabular}

Table 6. Site capacities (mol/kg) for FEBEX bentonite (Bradbury and Baeyens, 1997)

\begin{tabular}{llll}
\hline Site types & $\mathrm{S}^{\mathrm{S}} \mathrm{OH}$ & $\mathrm{S}^{\mathrm{W} 1} \mathrm{OH}$ & $\mathrm{S}^{\mathrm{W} 2} \mathrm{OH}$ \\
\hline $2 \times 10^{-3}$ & $4 \times 10^{-2}$ & $4 \times 10^{-2}$ \\
\hline
\end{tabular}

Table 7 Exchange cations (in meq/100 g) for FEBEX bentonite (Fernández et al., 2004)

\begin{tabular}{llllll}
\hline Cations & $\mathrm{Ca}^{2+}$ & $\mathrm{Mg}^{2+}$ & $\mathrm{Na}^{+}$ & $\mathrm{K}^{+}$ & $\mathrm{CEC}$ \\
& 34.62 & 34.01 & 31.18 & 1.94 & 102 \\
\hline
\end{tabular}

Table 8. Initial volume fraction (\%) of minerals (ENRESA, 2006b).

\begin{tabular}{ccccc}
\hline Minerals & Calcite & Anhydrite & Gypsum & Chalcedony \\
$\%$ volume fraction & 1 & 0.0 & 0.08 & 4.5 \\
\hline
\end{tabular}


Table 9. Calculated and measured 1:4 aqueous extract concentrations for bentonite sample 4.1 in Fig. 2. Also listed are concentrations inferred for the original sample at a gravimetric water content of $25.7 \%$ (concentrations in $\mathrm{mol} / \mathrm{L}$ ).

\begin{tabular}{ccccccccc}
\hline & $\mathrm{Ca}^{2+}$ & $\mathrm{Cl}^{-}$ & $\mathrm{HCO}_{3}{ }^{-}$ & $\mathrm{K}^{+}$ & $\mathrm{Mg}^{2+}$ & $\mathrm{Na}^{+}$ & $\mathrm{SO}_{4}{ }^{2-}$ & $\mathrm{pH}$ \\
\hline Inferred & $1.5 \times 10^{-3}$ & $1.4 \times 10^{-2}$ & $1.3 \times 10^{-2}$ & $4.9 \times 10^{-4}$ & $5.510^{-3}$ & $3.5 \times 10^{-2}$ & $4.1 \times 10^{-2}$ & 7.4 \\
Calculated & $5.5 \times 10^{-5}$ & $6.8 \times 10^{-4}$ & $3.5 \times 10^{-3}$ & $1.1 \times 10^{-4}$ & $1.6 \times 10^{-4}$ & $7.6 \times 10^{-3}$ & $2.1 \times 10^{-3}$ & 9.0 \\
Measured & $5.5 \times 10^{-5}$ & $6.8 \times 10^{-4}$ & $2.7 \times 10^{-3}$ & $1 \times 10^{-4}$ & $1.6 \times 10^{-4}$ & $7.6 \times 10^{-3}$ & $2.1 \times 10^{-3}$ & 9.1 \\
\hline
\end{tabular}




\section{DISCLAIMER}

This document was prepared as an account of work sponsored by the United States Government. While this document is believed to contain correct information, neither the United States Government nor any agency thereof, nor The Regents of the University of California, nor any of their employees, makes any warranty, express or implied, or assumes any legal responsibility for the accuracy, completeness, or usefulness of any information, apparatus, product, or process disclosed, or represents that its use would not infringe privately owned rights. Reference herein to any specific commercial product, process, or service by its trade name, trademark, manufacturer, or otherwise, does not necessarily constitute or imply its endorsement, recommendation, or favoring by the United States Government or any agency thereof, or The Regents of the University of California. The views and opinions of authors expressed herein do not necessarily state or reflect those of the United States Government or any agency thereof or The Regents of the University of California.

Ernest Orlando Lawrence Berkeley National Laboratory is an equal opportunity employer. 